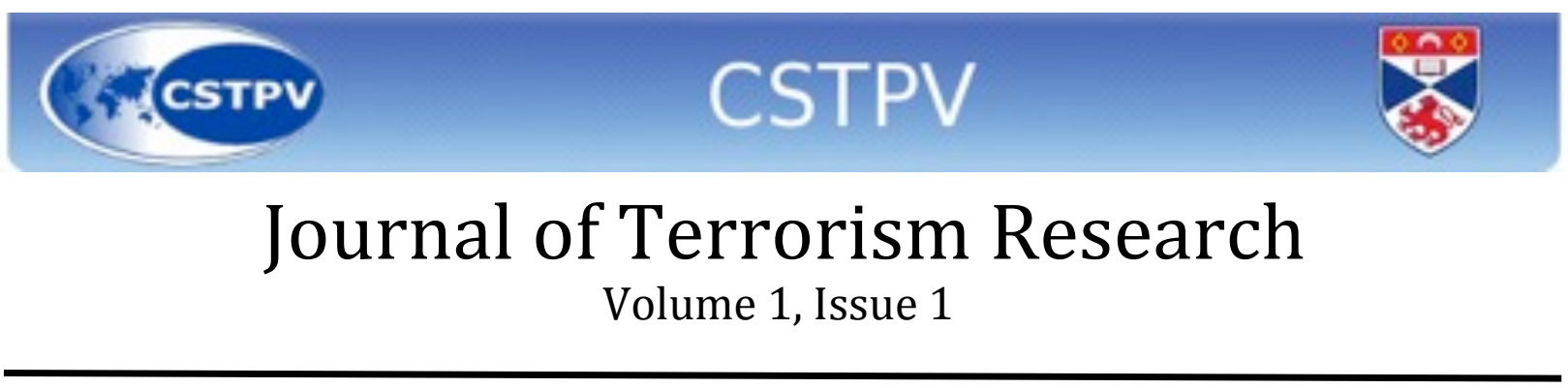

\title{
Revenge or Reward? The case of Somalia's suicide bombers
}

\section{by Dr Stig Jarle Hansen,}

\section{Associate professor in International Relations,} University Of Life Sciences, Ås

This article explores the social mechanisms that lead to the emergence of suicide attacks in new theatres, as well as factors influencing the frequency of such suicide attacks, by studying one of the states in which suicide attacks have most recently occurred - Somalia. The article argues that a suicide attack in the Somali setting seems to be a well-planned reaction to diplomatic or military moves by opposing parties in the conflict. However, it also poses that the initial emergence of suicide attacks in Somalia is grounded in ideological elements new to Somalia. The article thus argues that while frequency variations in suicide attacks are best understood as the result of rational calculations within an organisation, ideological elements and organisational belief systems have to be explored in order to understand the initial adoption of suicide attacks in Somalia.

\section{Introduction}

In early March 2007, Adam Salad Adam started work as a salesman, selling watches, clothes and electronics to Ethiopians and Somalis in the vicinity of Tarbuunka in Mogadishu, Somalia. On 26 March, he drove his Toyota through the first checkpoint guarding a local Ethiopian base. Adam Salad Adam's car was loaded with explosives; his plan was to detonate the charges as close as possible to the Ethiopian military base. He did not intend to escape from the explosion. He was a suicide bomber, part of a relatively new phenomenon in Somalia.

When the car exploded at the gate of the base, close to the cantina of the Ethiopians, 63 Ethiopian soldiers died and 50 were wounded. The 26 March attack was the first Somali suicide bombing that was filmed, a film that was later posted on the Internet. It signalled a new trend in Somalia. Before 2006, there had been no recorded suicide attacks in Somali history; from 2006 to February 2010 (when this article was written), there were 20 confirmed suicide attacks, as well as several other alleged cases. Sub-Saharan Africa, for the first time, witnessed a theatre with the systematic and prolonged use of suicide bombings. The Somali case is part of a global pattern. In the last ten years, suicide attacks were adopted for the first time in Afghanistan (9 September 2001), in Chechnya (7 June 2000) and in Iraq (26 February 2003).[1] Bruce Hoffman has found that 80 per cent of suicide attacks since 1968 occurred after 11 September 2001.[2]

There have been many attempts to explain the phenomenon of suicide bombing. One approach is to focus on individual suicide bombers and their ostensible psychological or economic problems. However, the consistency of social and/or psychological problems amongst suicide bombers 


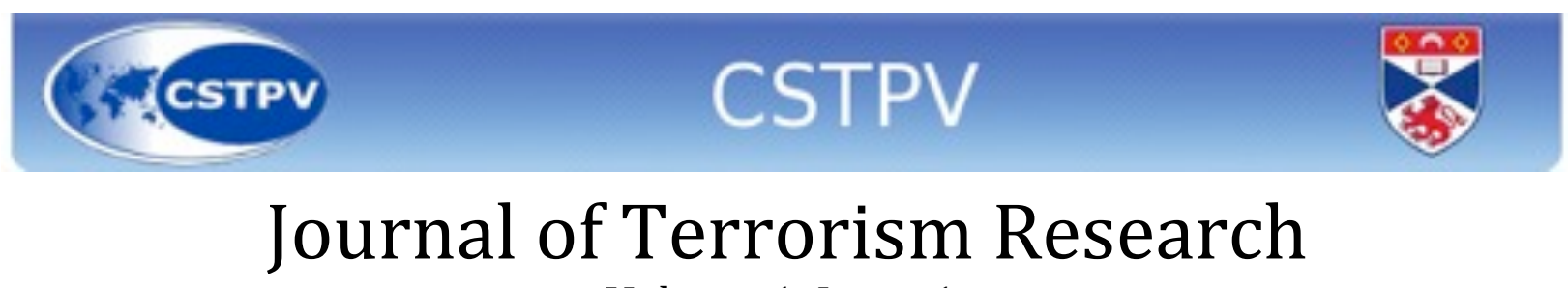

\section{Volume 1, Issue 1}

varies from case to case - being absent in the Sri Lankan, Iraqi, Pakistani and Palestinian cases but present in the Chechnya and Afghanistan cases. [3] It is important to note that the focus on individual psychological/economic/social factors fails to explain longer suicide campaigns. In order to sustain a long-term suicide campaign, several individuals have to be involved. Suicide attacks are thus a group phenomenon rather than an individual phenomenon, and in most suicide attacks there are organisations involved.[4] Systematic recruitment efforts, experienced planners and logistics are important factors in the execution of any sustained organisational effort, including that of suicide attacks. [5] Suicide attacks can be viewed as a specific type of tactic employed in order to achieve a specific goal, as the result of a planning process, and as a tool comparable to other strategies in asymmetric warfare such as guerilla attacks or remotecontrolled bombs. The suicide bomber thus becomes the low-cost equivalent of a cruise missile able to seek out weak points in the defences of the enemy, and, in disguise, even with a potential stealth capacity. Applying suicide attacks may thus be seen as the result of learning from the successes of such strategies in other conflicts. In fact, in his book "Dying to Win", Robert A Pape focuses on learning from the successes of suicide tactics as one of the major factors that prompt an organisation to adopt suicide terrorism.[6] Pape focuses on suicide attacks as an organisational phenomenon, and his approach examines the adoption of suicide tactics as a reflection of rational cost-benefit calculations on the part of strategic decision makers. However, Pape's claims have been strongly criticised. Assaf Moghadam shows that only four out of 17 suicide terrorist campaigns have led to a successful outcome.[7] Similarly, Brym and Arj show that Palestinian groups implemented suicide strategies despite clear knowledge that these strategies had few positive political effects. [8] Their critique is timely but may overlook the tactical gains that suicide strategies can achieve and the smaller local rewards that improve the standing of the implementing organisation. A conflict does not need to be won through suicide attacks in order for a suicide strategy to be applied so as to gain advantage over an enemy or a rival. Suicide attacks provide valuable media exposure to groups in asymmetric conflict situations, drawing local and possibly global attention to their grievances, and creating a lowcost and sustainable environment of insecurity that can force the opposition to the negotiating table.[9] When applied in a state-building context, suicide bombing also attracts attention to the failures of the state- builders.[10] Suicide attacks can also, in the right circumstances, be a method of generating grass-roots support for an insurgency. The use of suicide attacks becomes a demonstration of ideological commitment, as the act itself demonstrates a willingness to make a total sacrifice for a cause.[11] It may also be a good alternative for hitting hardened and wellprotected targets that would anyway have created casualties for the attacker. [12] Suicide attacks thus provide recruitment advantages for an organisation against other rivals' armed factions that are fighting the same enemy. This is the essence of Mia Bloom's so-called out-biding thesis, 


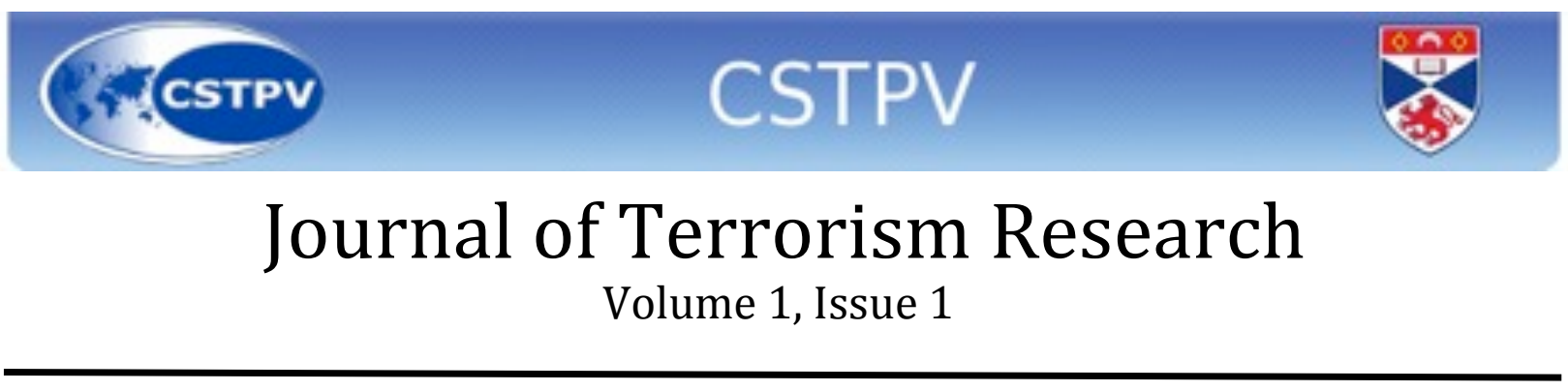

which views suicide attacks as a recruitment strategy in the competition with other groups fighting a similar enemy.[13]

\section{Why so few suicide bombers?}

According to the line of argumentation above, the initial adoption of suicide attacks and the frequency of such attacks should correlate with a belief that some form of organisational reward (in this life), either politically or tactically, is estimated by the challenger to be sufficient to justify the costs of suicide bombing - namely the deaths of the suicide bombers and potential hostility towards the strategy owing to local and international antipathy. These explanations see suicide attacks as the result of a rational calculation process, where the initial adoption becomes a result of learning, of seeing examples of its successful adoption both locally and internationally, and of employing suicide attack as a form of military tactic, employed to gain advantage at a tactical level against an enemy or popularity in the face of rivals. Frequencies of suicide attacks should thus increase when such strategies are needed and when organisations are facing hardship, trying to establish themselves in new areas or trying to gain attention.

Why then do not all organisations employ suicide attacks when they can gain from it? Firstly, the high human cost may limit the application of suicide bombing strategies to desperate situations. Ami Pedahzur, Stephen Hopgood and Berman and Latin, for example, see suicide attacks as a strategy in asymmetric warfare, in which one party is superior to another party. Suicide attacks then become the desperate strategy of a weak opponent challenging a stronger enemy.[14] Yet factions in Somalia have fought asymmetric battles without resorting to suicide attacks, being defeated and destroyed. In their "Club model", Berman and Latin also suggest that organisations that have high entry costs for members, and thus have very committed members, are the most common employers of suicide attacks. However, this overlooks the high entry costs and high commitment of several insurgent organisations that nevertheless have not led to the application of suicide attacks.[15]

Another approach argues that suicide attacks are more a question of revenge. Pedahzur claims that counter-terrorism strategies actually influence the decision to apply suicide attacks. Collective punishment and large-scale killings create an environment where suicide action becomes more accepted.[16] Barry Weingast and Rui de Figueiredo's argument is that violence tends to follow a retaliatory pattern, resulting in cycles of violence.[17] Robert J. Brym and Bader Araj stress the importance of the counter strategies; they claim that extreme countermeasures, such as assassinations and the use of heavy artillery, lead to an increase in suicide attacks.[18] Araj also points out that suicide attacks can be used as a form of revenge, a way to punish an opposing enemy for atrocities.[19] He illustrates this point by showing how, by 2006, Palestinians were already aware of the fact that suicide attacks increased extremism and 


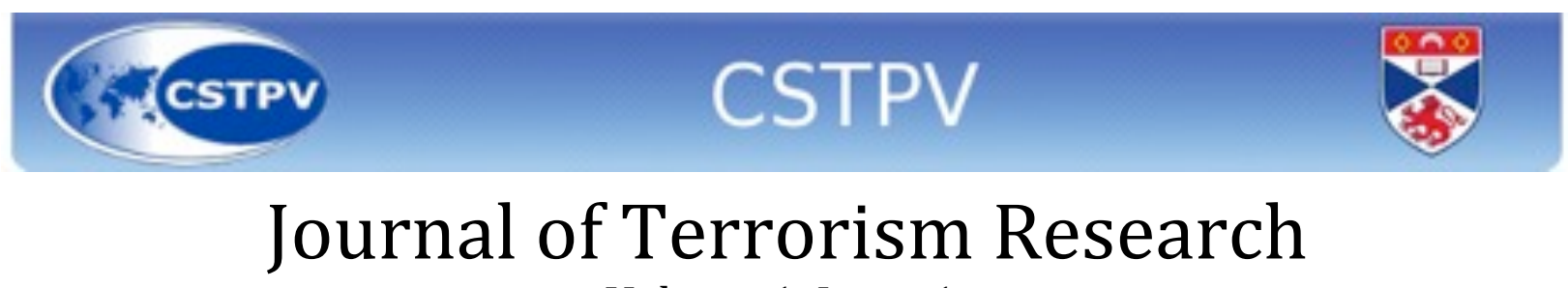

\section{Volume 1, Issue 1}

determination in Israel, yet nevertheless they supported suicide attacks.[20] Such an approach seems related to a psychosocial approach, exploring collective traumas. Evelin Lindner claims that collective/group humiliation, the feeling that 'our' societies are worse off than our enemies', mixed with historical entrepreneurs playing on these feelings, may create terrorism, including suicide terrorism.[21] Her view was that collective experiences may create fertile ground for suicide strategies; therefore, a humiliating invasion and a high frequency of war traumas become factors that could act as motivators for group actions. Luca Ricolfi sees collective humiliation such as this as a factor for increasing recruitment, making suicide missions easier to conduct, and enabling other motives to operate, for example the need for fame. The humiliation would make the general population more appreciative of the act of the suicide bomber, thus ensuring that a suicide bomber wanting fame and sympathy would get this.[22] One of Robert Pape's arguments may seem to run parallel with this type of argument, as he maintains that suicide attacks are the result of occupation, that they are a form of resistance against an invader. However, there are frequent experiences of violence, humiliation and dreadful collective experiences around the world, and perhaps particularly so in the case of Somalia and the general region of the Horn of Africa, that do not lead to any form of suicide attack, even though some of them pit a Christian occupying power/invader against Muslims; there must be other mechanisms at work as well.[23] Perhaps religion or culture could be such mechanisms? [24] Mia Bloom argues that community acceptance (or rejection), often influenced by elements within the local culture, is essential in determining both the initial adoption and the frequency of suicide attacks.[25] Another purported explanation focuses on the religious rationality behind suicide attacks. David Bukay, for example, argues that suicide bombing is created by religious beliefs. Bukay claims that Islam in particular has a clear theological foundation for suicide attacks, and that this foundation is a vital factor in explaining why suicide attacks occur.[26] Stephen Dale's argument runs parallel to Bukay's, suggesting that cultural traits of resistance activated when Islam faces occupation powers create suicide bombing, rather than traits of Islam per se.[27] However, any explanation focusing on the general traits or culture of Islam, or even Islamic resistance to invasions, is highly problematic, particularly in the Somali case. Somalis have been fighting several wars with neighbouring Christian-dominated Ethiopia since the sixteenth century, yet suicide attacks only occurred in 2006. Given that Somalia is overwhelmingly a Muslim country, and that suicide attacks are a relatively new occurrence despite a lengthy period of civil war, explanations that highlight Islam as a causal factor seem to be misleading, even when ostensibly Christian nations have engaged in Somalia before, such as the United States (1993-1994), and Ethiopia's, albeit short, interventions $(1996,1998)$. 


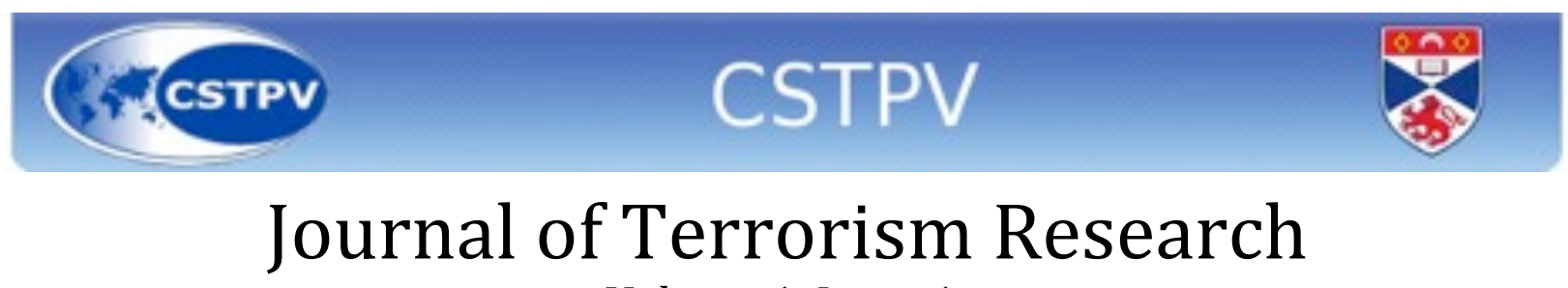

\section{Volume 1, Issue 1}

Another possible approach is to limit the scope more and to examine specific ideologies within Islam. Salafism, or Salafi jihadism, has been blamed for the spread of suicide bombings.[28] Such an approach also encounters large problems. As Sheik Khalil Ameer from the former Eritrean Islamic Jihad and Sheik Ali Gawish of the Sudanese Muslim Brotherhood express it, mixing elements from Salafism with other types of Islam is relatively common, and some groups will retain some elements from mainstream Salafism while discarding others.[29] Salafists are far from a homogeneous group; the term itself is broad and vague and can be misleading and overly broad when applied to politics and ideological studies. Even when Salafi jihadism is defined narrowly, it encounters problems. As Thomas Hegghammer points out, there were few Salafi jihadist groups that carried out suicide attacks before 2000, so Salafi jihadism in itself fails to offer a satisfying explanation for suicide attacks.[30] A more specific approach may perhaps be needed. Such an approach may avoid the trap of generalising about vague concepts such as religion or culture, while at the same time maintaining the focus on elements within a religious/ ideological belief system held by a particular organization, or at least powerful elements within them. Such ideational elements could be common to some organisations rather than to a religion as such, and could be traits that even secular organisations may internalise. Diego Gambetta, for example, focuses on shaheedness, a destructive martyrdom, martyrdom in war rather than in peace. Farhad Khosrokhavar similarly emphasises "offensive martyrdom" which is employed against heretics and non-believers, while Muhamed M. Hafez emphasises "the culture of martyrdom" as a result of victimisation and the active self-reinforcing of organisational rites. However, a case study of Somalia may give us the opportunity to delve deeper into the belief systems of specific organisations, as well as sub-groups within them, and to identify more such elements.[31]

It is important to note that rationality-focused explanations do not necessarily contradict a focus on components of organisational belief systems, as suggested by Elisabeth Kier, as such elements may define strategies or targets that are incorporated into a rational calculating process. Nor do rationality-focused arguments necessarily contradict a humiliation hypothesis, humiliation simply defining the goals of a rational actor.[32] This article claims that, in the Somali case, suicide bombings have followed a pattern that indicates a rational organisation strategy that is designed to face new challenges; it is a type of tactic chosen because of the benefits it has brought the organisation. Nonetheless, the third section of the article will claim that a benefitfocused hypothesis alone fails to explain the initial adoption of suicide attacks. The article argues that to understand the initial emergence of suicide terrorism in Somalia, it is necessary to explore the set of beliefs held by powerful elements of the Harakat Al Shebab group, who are the primary, if not the only, agent of suicide attacks inside Somalia. This is explored not by 


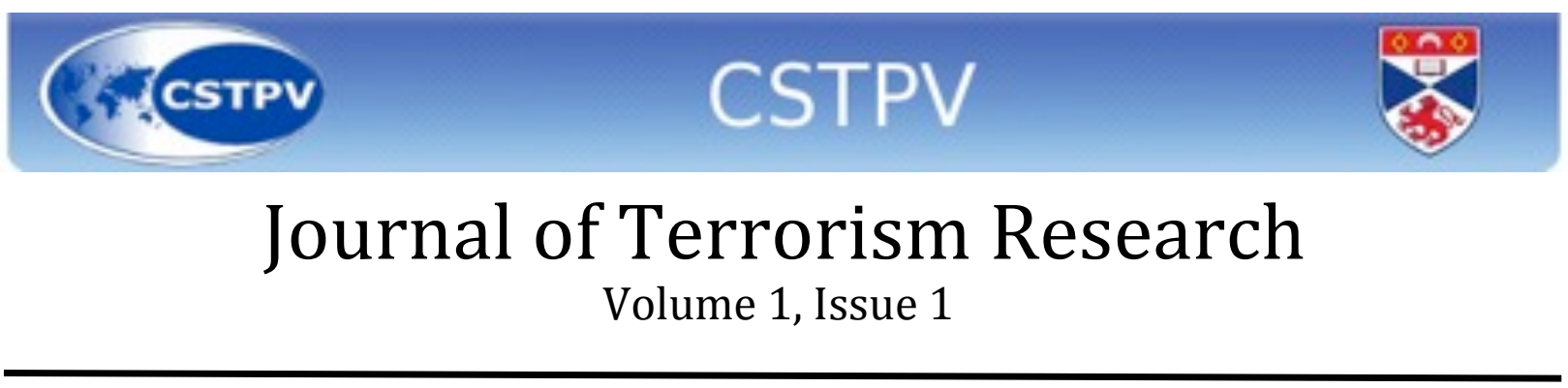

employing a broad concept such as Salafi jihadism or Islam, but rather by analysing the specific elements that separate the Shebab from other groups in the Somali setting.

\section{The structure of the Somali suicide attacks}

Although Somalis may have been involved in suicide attacks outside of Somalia before 2006, the first alleged suicide attack within Somalia took place on 18 September that year.[33] The attack targeted a convoy with the then-president of the Somali Transitional Federal Government (TFG), Abdullahi Yusuf. The attack took place in confusing circumstances, and no person or organisation took responsibility, as the TFG had a strong interest in convincing the global media that it was a suicide attack by radicals with connections outside Somalia because of a need to gain Western support for their struggle against their then-rivals, the Supreme Council of Islamic Courts (SCIC) in Mogadishu. Nevertheless, the next attack was confirmed by independent sources and was claimed by a group, and fits into a pattern when compared with later attacks: on 30 November 2006, an Ethiopian control post on a road leading into Baidoa (at Daynuunaay) was targeted by a suicide bomber.[34] A local commander of the Al Bayan Sharia court formally part of the alliance of Sharia courts, the SCIC - Mohamed Ibrahim Said Bilal, claimed responsibility for the attack. Bilal's declaration of responsibility seemed to contradict his supposed superiors within the SCIC, and the latter publicly distanced themselves from the attack. [35] Bilal's special connections with more radical Afghanistan veterans within the SCIC may explain this difference of opinion, as he was at the time (through the Al Bayan court) working for Afghanistan veteran Muqtar Robow "Abu Mansoor", who later became one of the leaders of the Somali radical Al Shebab organisation.[36] Al Shebab has since become the foremost agent of suicide attacks in Somalia, indeed no other group has ever publicly acknowledged responsibility for suicide attacks.[37] This first confirmed attack illustrates how suicide attacks in Somalia were launched by a group of radicals within the Sharia courts rather than by the Sharia courts themselves. It also illustrates how the Sharia courts distanced themselves from the suicide attacks, even those against ostensibly Christian Ethiopia. In fact, it seemed as though the courts did not need to use suicide bombs, that there was a balance of power between the belligerents, and many believed that the Ethiopians would be defeated.[38] While Somalia's first suicide attack came in this period, the frequency compared with later periods was low, there being only one confirmed, and one possible attack in the whole of 2006.

In December 2006, local clashes escalated into outright war between the SCIC and the TFG supported by Ethiopia. The SCIC was rapidly defeated in a humiliating campaign. By the end of January 2007, the SCIC's institution was shattered and its members were on the run; the TFG and its Ethiopian allies asserted control over central and southern Somalia but refrained from occupying parts of the capital, Mogadishu. The start of Somalia's first wave of suicide attacks 


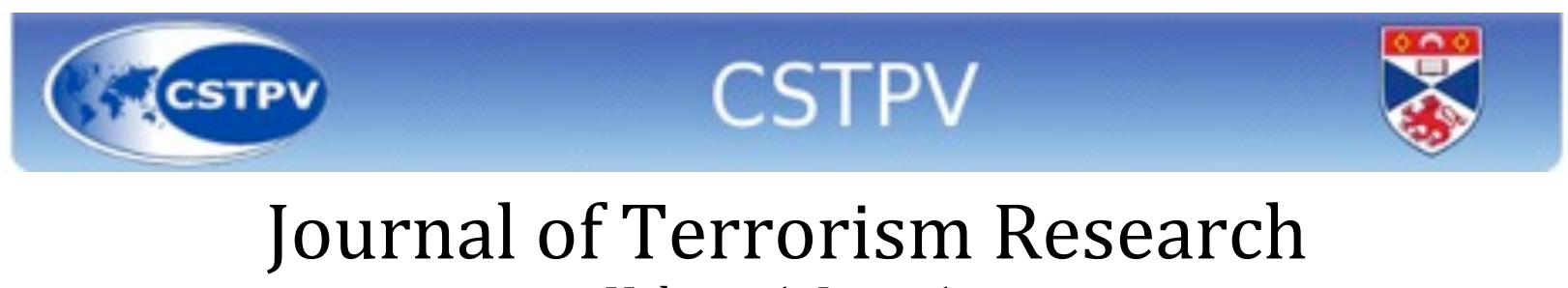

\section{Volume 1, Issue 1}

coincided with a large Ethiopian offensive to conquer parts of Mogadishu, an offensive that started in March 2007.[39] In the period from March to April, fighting was intensive in Mogadishu.[40] The impact of the fighting on the civilian population was devastating:[41] by late April, the UN estimated that at least 365,000 people had fled the city.[42]

At the time, Al Shebab was one of many insurgency groups and was in the process of reestablishing itself after its collapse in late December 2006. Before its use of suicide attacks, Al Shebab was by and large ignored by the media, although this changed as suicide attacks became more frequent. Suicide attacks targeted Ethiopian bases and led to a large number of casualties ; thus they had a purely military value. The suicide wave also occurred simultaneously with the defeat of the insurgents; they were attacked and humiliated by superior forces, and were clearly outmatched.[43] The attacks could thus be the result of a wish for revenge because of a collective humiliation due to the Ethiopian intervention/invasion; indeed Adam Salad Adam's suicide video depicted his attack as a revenge tactic for a rape conducted by Ethiopian forces.[44] The Somali pattern of suicide attacks before 2007 do not indicate this. Firstly, although Ethiopia had intervened regularly during the years 1996-1998, this did not result in suicide attacks, even from Somali Islamist organisations, although Ethiopians severely crushed their bases. Not even during the larger Ethiopian-Somali Ogadeen war in 1977-78, taking place in Somali-inhabited lands, did suicide attacks occur. Secondly, although Ethiopia had had a military presence in areas of Somalia since spring 2006, only the two previously-mentioned suicide attacks (of which one seems to have been a bomb-attack rather than a suicide attack) were registered between September 2006 and March 2007. It could be argued that it was the general suffering of the Mogadishu population during the March-April offensive in 2007 that prompted the suicide wave, given that the campaign took place in densely-populated Mogadishu. However, the Mogadishu population had suffered before the March-April offensive, such as during the UNISOM II intervention in 1993-1994 (which at the time bin Laden argued was a Christian invasion) and the so-called Four Month War in 1991, and no suicide attacks occurred during these periods. Even in 2006, only one organisation, the Harakat Al Shebab, implemented the suicide attacks; thus humiliation must have influenced other insurgent groups differently.[45]

From the end of May 2007, suicide attacks continued even after the Ethiopian withdrawal from Mogadishu and Somalia in 2009. Ethiopian presence was still felt in Somalia through fast raids and through support for Ethiopian allies. However, Ethiopian operations after 2009 were similar to Ethiopia's frequent interventions in 1995-2006, rapid raids rather than occupation, support for allies rather than commitment men of forces. Although Ethiopian forces deployed on short-term missions in Somalia before 2006 had provoked anger, they never provoked suicide missions, but after the 2009 withdrawal suicide missions continued. Suicide missions also took place during 


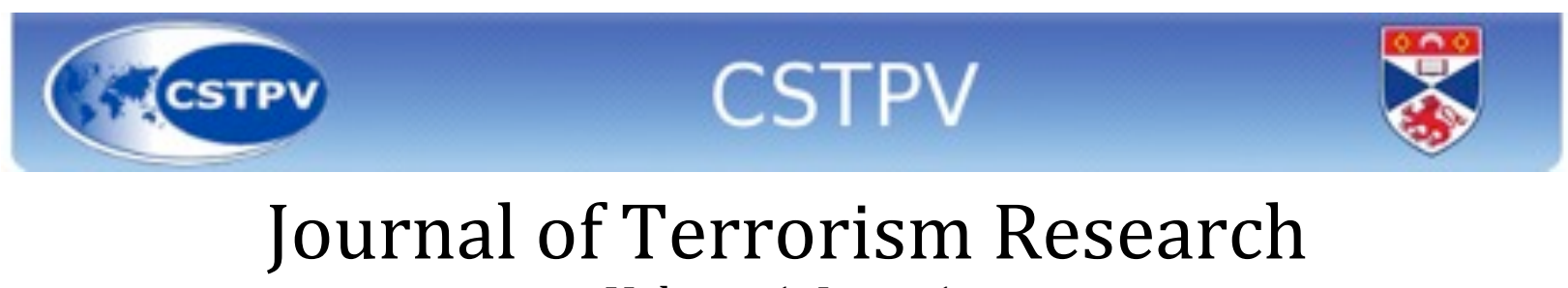

\section{Volume 1, Issue 1}

periods without intensive fighting. The suicide attacks seem rather to be correlated with the Shebab's need to gain attention, to establish itself in new areas or to damage peace and statebuilding processes. Once the March-April offensive ended, which was a humiliating experience for Shebab, the Ethiopians and their Somali allies won in Mogadishu, the rate of suicide bombings decreased and remained low until October 2008. This decline is best explained by the tactical situation on the ground. During the summer of 2007, Al Shebab was reorganising, was gaining attention on both the Somali and the international stage, and was adjusting to using guerrilla tactics in its operations. At this time, all rebel groups abstained from holding territories and resorted to hit-and-run attacks, which made them less vulnerable to large-scale TFG/ Ethiopian offensives, but they were expanding the geographical and operational scope of their attacks. Although the humiliating experience of the Ethiopian presence in Mogadishu remained, there was no desperate need to stop large TFG/Ethiopian offensives and no need to gain attention. The Shebab was on the offensive both in the media and militarily.

The first suicide attack after the summer of 2007 was the 11 October 2007 suicide attack targeted at the TFG prime minister in Baidoa, hitting a factory close to his hotel. It was the only suicide attack during the autumn of 2007, and it coincided with the Harakat Al Shebab establishing a military presence in the region, apparently drawing attention to Al Shebab when it was organising itself in a new area.[46] Following the October 2007 attack, only one attack took place over the next year. Suicide strategies were not needed, and other strategies served the aims of the Harakat Al Shebab perfectly.

However, during the summer of 2008, the TFG started negotiating with a powerful and popular faction (as it was then perceived) of the opposition in Djibouti. At first these negotiations were cumbersome and few believed that they could succeed, but by the autumn of 2008 the talks produced tangible results. On 26 October 2008, the two parties in the Djibouti process - the Alliance for the Re-liberation of Somalia, Djibouti group (ARS-D) and the TFG - announced a ceasefire.[47] At the time, the agreement was popular within Somalia and was supported by the United States as well as by several of the veteran Islamists within the old SCIC. The mood amongst diplomats in Nairobi was frantically positive. As the focus shifted onto the Djibouti process, the insurgents lost media attention and were threatened politically and militarily; even worse, increased military deployments from the African Union and United Nation forces were seriously discussed. The insurgents' response was swift: the Shebab attacked the city of Merka. Almost simultaneously, a suicide video of Abdulaziz Bashar Abdullahi's attack against the African Union forces in April 2008 was released. Then Somalia's largest and most wellcoordinated wave of suicide attacks began on 29 October 2008.[48] The wave of attacks succeeded in shifting attention away from the diplomatic triumphs of the new negotiation 


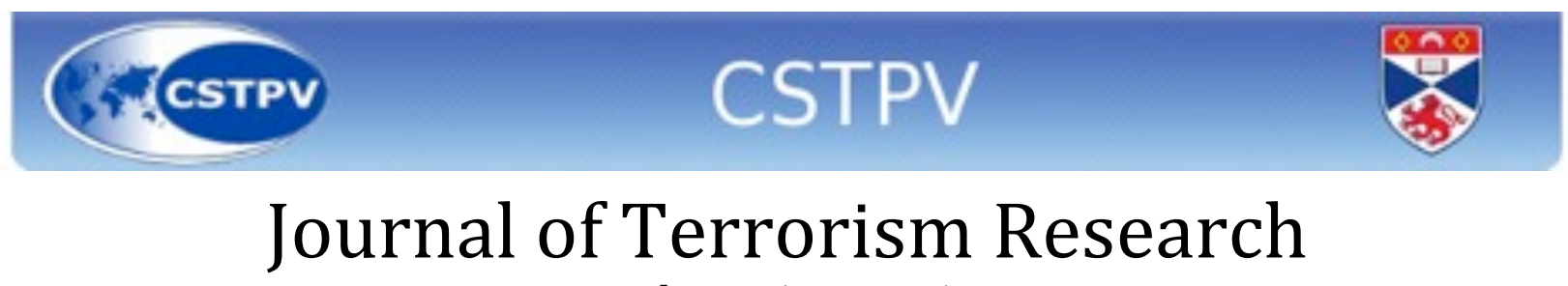

\section{Volume 1, Issue 1}

process and back to the insurgency, and contributed to the deterrence of the potential UN and AU peacekeeping contingents for Somalia which were discussed within the United Nations and the African Union.[49]

The Djibouti peace process was not derailed by the 29 October attacks, and once the Ethiopians withdrew from Somalia in January 2009, Mogadishu became more peaceful until May 2009. However, despite this, suicide attacks within Somalia increased. On 24 February, an alleged suicide bomber exploded when Somali police opened fire on a suspicious car in Mogadishu. On 21 February 2009, two suicide bombers - one suicide car-bomber and one bomber using an explosive vest - attacked the forces of the African Union in Mogadishu.[50] Both the new transitional government, led by former SCIC leader Sheikh Ahmed Sheikh Sharif, which was then popular both within Somalia and amongst the Diaspora but which is now in decline, and the fact that this transitional government was supported both by the West and by notable Islamists such as Yusuf Qaradawi, presented an increasing threat to the Shebab, drawing attention away from it. It is important to note that if the Ethiopian presence in Somalia caused the suicide bombing, its withdrawal from all of its permanent bases would be expected to lead to a decline, but it did not. As the Ethiopians withdrew, the numbers of attacks remained constant. The June 182009 attack by suicide bomber Muxamed Deerow Shiikh Aadam (zubayr) targeting the new government's head of security Omar Hashi Aden on 18 June 2009 - seems to have been thoroughly planned and caused chaos in the government's security apparatus, paving the way for the Shebab's tactical victories during the summer of 2009. In fact, suicide attacks in Somalia seem to have been thoroughly planned as part of an organisational strategy to balance the odds and to gain attention, and they have been highly effective. Suicide bombing seems to be guided by a rational process, in which the targets and the timing are carefully selected to achieve the political and strategic aims of the Harakat Al Shebab. While suicide bombing has not succeeded in bringing large strategic victories to these groups, it has succeeded in bringing them media attention and has contributed to a general environment of insecurity that can be used for propaganda purposes.

The initial humiliation of the Ethiopian intervention does not explain the pattern of the suicide attacks nor does the humiliation of the Mogadishu offensive during the spring of 2007. Suicide attacks took place even after Ethiopia had withdrawn most of their forces from Somali territory, in a period where the Ethiopian raids were very similar to past Ethiopian presence in Somalia during the civil war (which never led to suicide attacks), and during periods of relative peace. Political and military challenges facing the Shebab are better predictors of suicide attacks. For the Harakat Al Shebab, the main initiator of suicide attacks, it seems that suicide strategies remain a specific tool in their military and political campaigns, a tool comparable to guerilla 


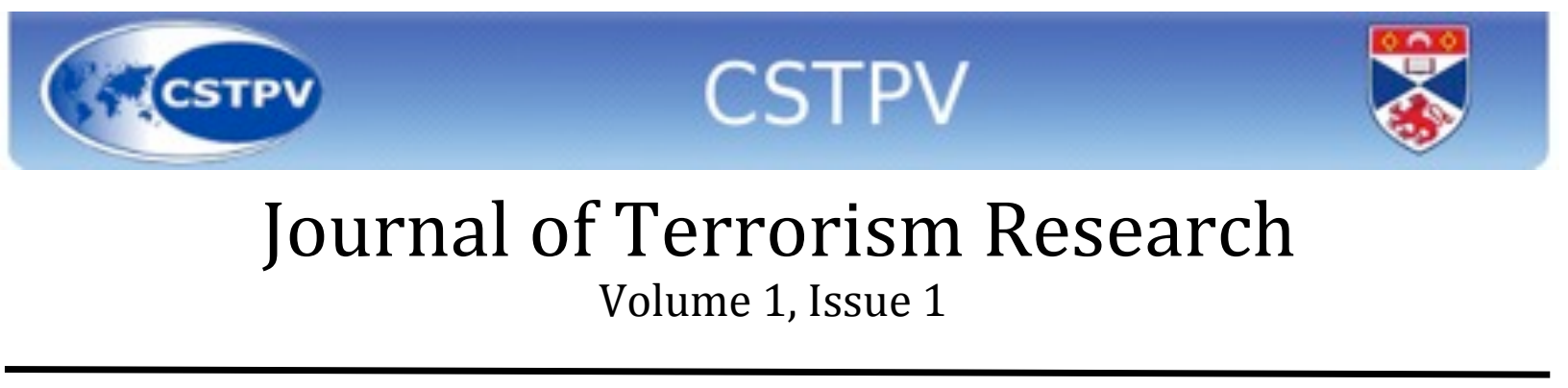

attacks, ambushes, and remote-controlled bombs. However, the above discussion does not explain why a suicide bomber strategy has not been adopted by other factions in Somalia, and why Al Shebab and not other factions have implemented the majority of the attacks.

\section{Why was suicide bombing adopted?}

Bruce Hoffman has found that 80 per cent of suicide attacks since 1968 occurred after the September 11 attacks.[51] It seems as though the attention caused by the September 11 suicide bombing contributed to an increased interest in the strategy around the world, and Somalia is part of this pattern. Such an argument presents us with a riddle: if this interest was general, why did only one organisation in Somalia, the Harakat Al Shebab, publicly claim to use the strategy?[52] No other Somali organisation to date has ever published suicide videos or claimed responsibility for suicide attacks, and it is doubtful that any other organisation has attempted to use suicide tactics.[53] Other rival insurgent groups have been in desperate situations that could have justified suicide tactics, but they have nevertheless publicly refrained from using such tactics. [54] One reason for the lack of suicide bombings conducted by other organisations in Somalia is what Mia Bloom refers to as community rejection. Somali society has no tradition of suicide bombings, and to a certain extent the suicide tactic is alien to Somali culture - there has been no tradition of using suicide attacks in conflicts. There was no recorded suicide bombing in Somalia before 2006, and there is simply no historical tradition of suicide attacks.[55] In fact the Somali clan system to a certain extent discourages suicide bombings, as clans are seen as collectively responsible for the actions of individuals and suicide attacks could lead to retribution against a person's clan. The past fluidity of the Somali civil war, and its lack of ideology, and rather a focus on profit seeking also discouraged suicide missions. Many observers stated it was the Ethiopian intervention (occupation) that created suicide attacks.[56] However, previous interventions, which were shorter but in which Ethiopians took more direct control of land, and when the American-led AMISOM II or UNITAF more directly intervened or took control of large parts of Mogadishu, did not result in suicide attacks. Nor did Ethiopia's alleged occupation of the Somali-inhabited Ogadeen region, and various military campaigns this region, some with severe consequences and violations of human rights, result in suicide bombings. Moreover, only one out of many insurgent organisations, including other Islamist organisations, implemented suicide missions, even in the period of Ethiopian occupation 2006-2009. The most likely explanation for this is that the Islamist organisations that existed in previous periods, and other Islamist organisations active in Mogadishu 2006-2009, were different from the organisation implementing suicide attacks in Somalia in 2006, 2007, 2008, 2009 and today, namely the Shebab. In fact, the development of suicide attacks to a certain extent follows the development of one single organisation, the Harakat Al Shebab, which until 2006 was a loose, informal network 


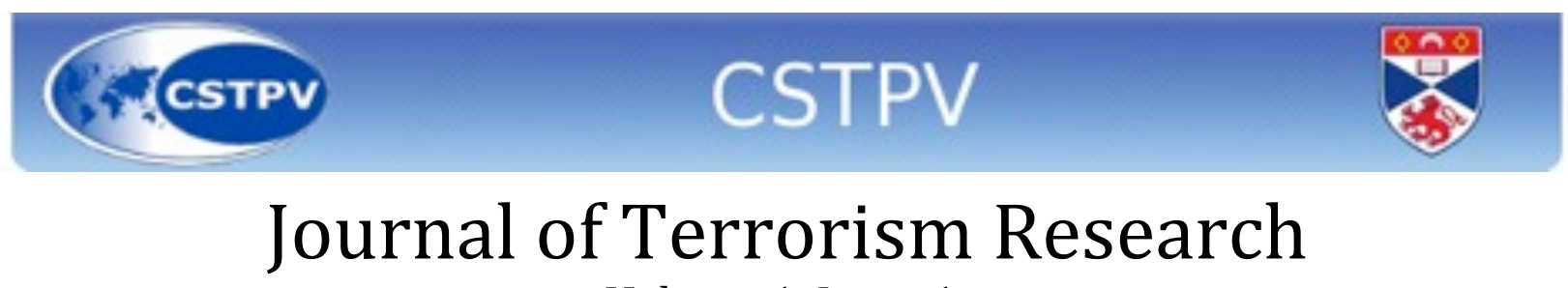

\section{Volume 1, Issue 1}

but by 2007 was growing into a separate organisation.[57] In the end, the suicide tactic was only publicly adopted by the Shebab or Shebab affiliates, and began as the group consolidated into an organisation.

The Shebab organisation originally consisted of a core group, of which many had a background from Afghanistan; it was ideologically strong enough to transcend clan from an early stage. Two of these members were found guilty in Somaliland courts for attacks against Westerners as early as in 2003 and 2004. The attacks were not motivated by profit but rather by hostility towards the West, and not taking place in a combat situation, something new in Somalia at the time, it also took the risk of replacing the Somali flag with a black jihadi flag during the fighting over Kismayo in 2006, claiming that the former represented secular borders, creating tension between them and the more nationalistic elements within the Sharia courts. However, the success of the group meant that other elements were recruited: profit seekers, local militia that wanted to be on the winning side, as well as Diaspora motivated sometimes by nationalistic, sometimes by clanish reasons. Nevertheless, elements of the original core group remained important, if not dominating, within the organisation. Moreover, they dominated the training of new recruits, both international and Somali, in the core areas controlled by the organisation.[58] The worldviews of the old core group of Shebabs remained important, and the qualities of ideologies adopted by powerful elements of the organisation were very different from all other Somali factions. At least three ideological traits separated these elements from most of Somalia's political actors. The first trait was the organisation's use of special pan-Islamist and jihadist rhetoric, in some instances closely resembling the rhetoric of Al Qaeda, always tending towards praise when that organisation was mentioned while denying being a part of it. In the words of the old Shebab head of public relations Muktar Robow, "That is all there is to it. We are not part of them (Al Qaeda) but we love them very much."[59] Ideologically, the Shebab leaders often declared the need to resurrect the pan-Islamic caliphate, putting their local conflict in a global framework of good versus evil. In this sense, the enemy was not only Ethiopia but also the West.[60] In many ways, their rhetoric strongly echoed Farhad Khosrokhavar's focus on the transnationalism of some of the modern martyrs, namely Al Qaeda's focus on the Global Ummah.[61]

The second trait separating the Shebab from other Somali organisations was their anti-nationalist rhetoric, as well as their critique of traditional Islamic groups in Somalia such as the Sufis.

Admittedly, Shebab probably recruited from youth hostile to the Ethiopian intervention and with a nationalist motivation for joining, even using implicit nationalistic like references to Ethiopian occupation in some of their videos, but the rhetoric of the leadership was to a certain extent surprisingly anti-nationalist, revolutionary in a Somali setting where most fractions publically have claimed their allegiance to the Somali nation (although often functioning as mere clan 


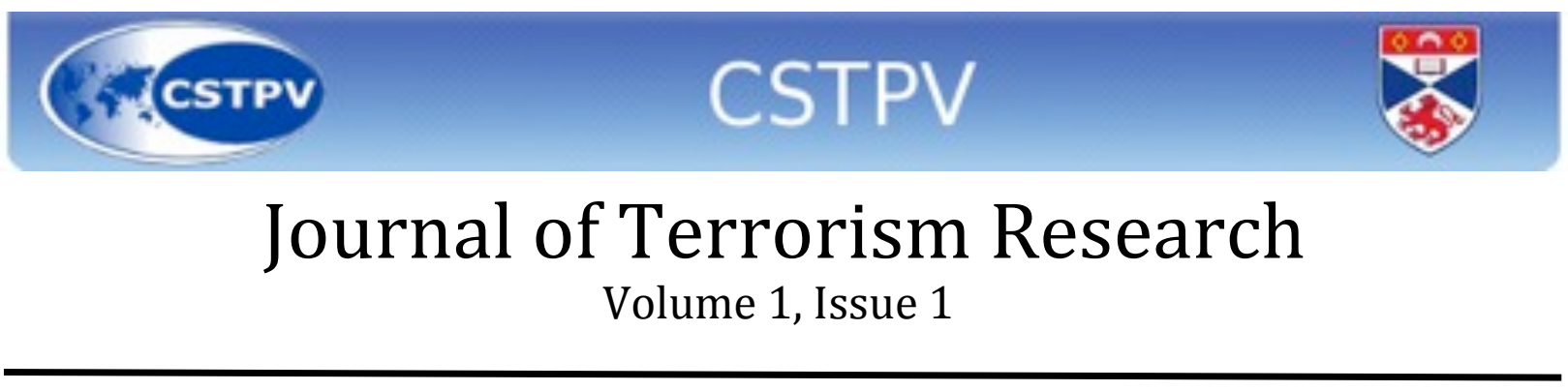

fronts).[62] Most of the known Shebab top leaders have made strong anti-nationalist statements. Former spokesperson Muktar Robow is perhaps the Shebab leader who most clearly defined the Shebab's attitude towards nationalism and patriotism, stating that "a nationalistic, patriotic bond is against the (Muslim) brotherhood bond", as well as criticising the organisation for replacing the jihad with "patriotic resistance".[63] Shebab leaders strongly and explicitly distanced themselves totally from the nationalist agenda.[64] Symbolically, the Shebab even refused/ refuses to use the Somali flag, tearing it down wherever possible. In this sense the Shebab, or at least most of the Shebab leaders, depict themselves as sharing ideology and motivation with other radical organisations with similar goals; and with four out of the eight leaders in the Shura council in 2007 with a background from Afghanistan, this seemed natural.[65]

The third trait also seems to have been borrowed from Al Qaeda - death worshipping, best illustrated by Abu Mansoor's remark

Our brother Ma'alin and our brother Umar Dheere alias Abu Jabal. Many of those who were present during the formation of the group have also been martyred. Those who are still alive are also looking forward to death, in order to die for the same cause that others before them died for.[66]

Shebab ideology, much more refined than its Somali predecessors, also provided stronger justifications for suicide attacks. Admittedly, there have been rifts even within the old core group of Shebabs - for example, between former press spokesman Muktar Robow and leader Abu Zubeir - but both parties, even the supposedly more moderate Muktar Robow, adhered to the elements described above, both in statements in the Somali press or on international jihadist websites and in interviews; and the two parties also seem to have become reconciled during the summer of 2009.[67] These three traits were important throughout the Shebab's organisational history and remain so today.

Shebab leaders were thus the only Somali leaders that publicly and repeatedly praised Al Qaeda. They framed their struggle in a global context; this approach deviated from all mainstream and traditional religious views in Somalia.[68] This indicated a willingness to adopt ideology from organisations with similar views and also indicated admiration for Al Qaeda, a major implementer of suicide attacks. In fact, it was almost natural that Shebab in the end borrowed the suicide strategy, amongst other elements, from Al Qaeda.

The above line of argumentation supports Thomas Hegghammer's view that elements within specific ideologies need to be explored rather than abstract notions such as Islam, culture or Salafism. Any attempt to explain the adoption of suicide bombing in Somalia that focuses on Somali or Islamic culture or religion can be misleading. Somalia and Islam have been tied 


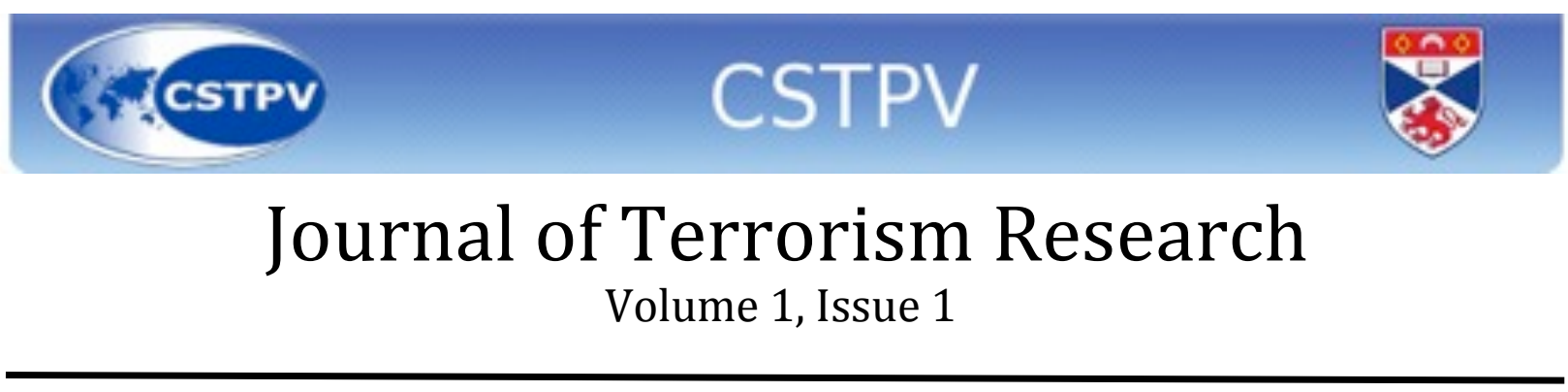

together for centuries during which there were no suicide attacks. Indeed, even today there are many Islamist organisations fighting alongside Al Shebab, but no known Somali Islamist organisation other than the Shebab implementing suicide tactics. An examination exploring the differences between the Shebab and the other Somali actors seems to indicate relatively large variations in ideology, and to show that there are certain tenets of some of the most powerful Shebab leaders that are alien to Somali society in general, but that are shared by other global jihadi actors. Rather than talking about an abstract notion of Somali culture or about religion per se, it may be more fruitful to talk about a specific belief system or a combination of more specific ideological elements. The most important point is that the Shebab's ideological traits contain indications that powerful elements within the organisation adopted ideological tenets from other organisations implementing suicide attacks - both indicating a willingness to learn from these organisations, in particular Al Qaeda, as well as providing justification for the use of suicide attacks. The fact that only the Shebab adopted suicide tactics seems to indicate that their openness to Al Qaeda's ideology, and the ideological elements borrowed from them justifying suicide attacks, are important in understanding their initial willingness to use suicide attack. In fact, the Al Qaeda-inspired ideological elements are what make the organisation stand out in the Somali political context.[69]

The situation in 2006-2007 created a window of opportunity for the special elements of Shebab ideology as well as for the Shebab itself. Similarly, the Iraq crisis had an impact in Somalia, and hostility towards the West increased.[70] In this sense, humiliation did play a role but only because of the ideological elements that allowed it to have an influence, and it had little influence on the variations in the frequency of suicide bombings. Statements by the leaders of the organisation indicate elements of a very specific belief system that were used to justify the use of suicide attacks, and that indicated a willingness to learn from external organisations sharing these elements. In examining suicide attacks, it may be fruitful to explore specific belief systems and shared perceptions of the world within smaller groups, rather than for example exploring whole religions; to study more detailed elements rather than to generalise about a religion or even larger sub-groups within that religion.

Pape's claims regarding suicide tactics as a form of resistance to physical occupation are misleading, as it is not occupation per se that creates suicide attacks. It is perhaps a specific element of ideology that enables not only occupation but also perceived humiliation - such as the Danish cartoon incident frequently depicted in Shebab suicide videos - to have an impact; it may be a depiction of a world of eternal struggle between an imagined community, the Umma, and everyone else, rather than national resistance to Ethiopian intervention.

\section{Conclusion}




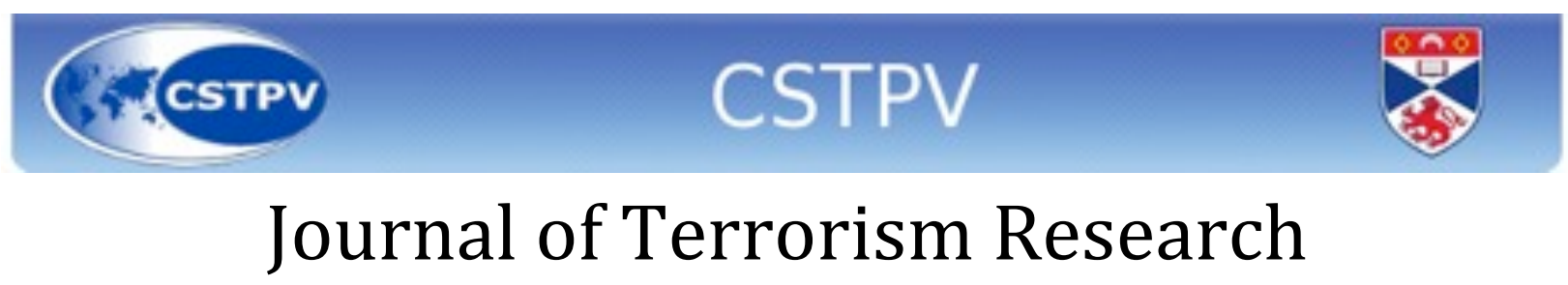

\section{Volume 1, Issue 1}

The main finding of this article is that the frequency of suicide bombings in Somalia varies according to the strategic needs of the Al Shebab organisation, indicating that the use of suicide bombing is a product of strategic reasoning. Suicide bombing is thus the result of a strategic cost-benefit calculation, wherein groups use this suicide tactic to gain attention, to gain political advantage and, in a few cases, to gain military advantage. Only in one period of suicide attacks in Somalia, between March and April 2007, does the traumatisation hypothesis have explanatory power; but even within this period, Al Shebab's strategic needs provide a good alternative explanation. This suggests that a view that focuses on the organisation implementing suicide attacks in order to increase its own power explains variations in the frequency of the tactic's adoption in Somalia.

However, a focus on organisational needs and rewards does not fully explain the initial adoption of suicide bombings in Somalia. Other Somali organisations could have adopted suicide attacks as a tactic but chose not to. The Shebab differed from these organisations in several of the ideological traits which its leadership claims to adhere to. An approach focusing on organisational rewards or organisational suicide tactics is not enough to understand suicide bombings in Somalia. Ideological elements, creating a belief system that provides some form of justification for suicide tactics alien to Somali culture, had to be in place to enable suicide bombing to take root. This suggests that a study of organisational beliefs, also the beliefs of organisational sub-groups, in general can be fertile when attempting to explore the organisations that will respond to organisational needs by adopting suicide attacks. The findings suggest that suicide bombings may fruitfully be approached through a combined rational actor/belief systembased model. In the Somali case, this offers some hope as the organisation that so far has claimed responsibility for most suicide attacks in Somalia, the Shebab, has drastically expanded its new membership. With a possible shift in the ideological orientation of the Shebab, the organisation may evolve and become less willing to use suicide attacks.

Dr Stig Jarle Hansen is one of the co-editors of the recent "Borders of Islam" anthology, Published at Colombia University Press, and has conducted extensive field research at the Horn of Africa as well as Yemen. Hansen holds a PHD from Aberystwyth, the University of Wales, and Mphils in History and Political Science from the University of Oslo/University of California at Berkeley. He is currently serving as associate professor in International Relations, Department of International, Environmental and Development Studies at the Norwegian University of Life Sciences.

This article was originally published on the 27/07/10 at http://www.st-andrews.ac.uk/ cstpv/jtr/ vlil/jtr1_1 hansen revenge.html

\section{Bibliography}




\title{
Journal of Terrorism Research
}

\author{
Volume 1, Issue 1
}

Abu Bakr Karshi (2008), “An interview with commander Abu Mansoor, Muqtar Robow” Sada al Jihad Magazine, Global Islamic Media Front, 25 (3).

Abu Zubeir (unknown) "Speech”, dated 01.062008.

AllAfrica/garrowe online "Somalia: 11 African Union Peacekeepers Killed” http:/allafrica.com/ stories/200902230003.html (accessed 23/03 2009).

Aljazeera.net "Bomber targets Ethiopian army base”, http://english.aljazeera.net/news/africa/ 2007/06/2008525122640510550.html, (accessed 25 February 2009).

Al Jazeera "Interview with Mukthar Robow Abu Mansoor" as aired on Al Jazeera 7 March 2009.

Al Shebab “Ambush (with speech by Abu Mansoor)” http://www.youtube.com/watch?

$\mathrm{v}=1 \mathrm{fkwlxzqd} 28$ (accessed on 23 April 2009).

Bader Araj (2008), "Harsh State Repression as a Cause of Suicide Bombing: The Case of the Palestinian-Israeli Conflict”, Studies in Conflict \& Terrorism, 31.

Berman, E. and Latin, D. (2004), "Rational Martyrs, Evidence from Suicide Attacks", Paper presented at the conference on suicide bombing, Stanford, September 2003.

Bengali, Shashank, "Kenyan Islamist recruits say they did it for the money", McClatchy Journal, 18 November 2008.

Bloom, Mia (2005), Dying to kill, the allure of suicide terrorism, Colombia University Press, New York.

Brym, Robert J. \& Araj, Bader (2006), "Suicide Bombings as Strategy and interaction: The case of the Second intifada", Social Forces, 84 (4).

Bukay, David (2006), "The Religious Foundations of Suicide Bombings Islamist Ideology”, Middle East Quarterly, Fall 2006.

Bunker, Robert J. and John P. Sullivan (2005), "Suicide Bombings in Operation Iraqi Freedom”, Military Review, January-February 2005.

Dale, Stephen (1988), "Religious suicides in Islamic Asia: Anticolonial Terrorism in India, Indonesia and the Philippines", Journal of Conflict Resolution, 23.

Davis, Joyce M. (2003), Martyrs Innocence, Vengeance and Despair in the Middle East, New York, Palgrave.

De Figueiredo, Rui and Weingast, Barry (1998), "Vicious Cycles: Endogenous Political Extremism and Political Violence", paper presented at the annual meeting of the American Political Science Association, Boston, September. 


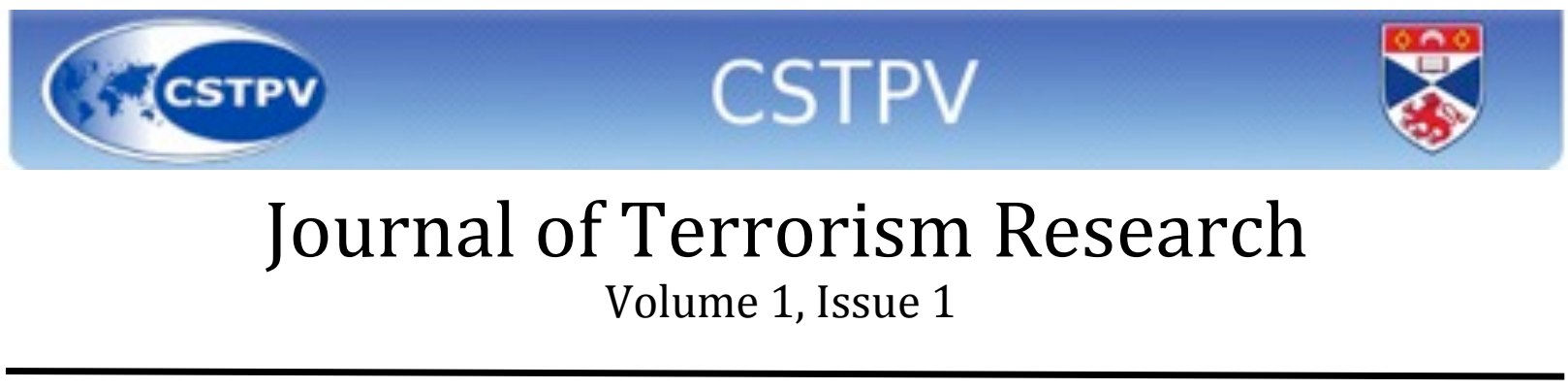

Fair, Christina, Who are the Pakistani Militants and Their Families, Terrorism and Political Violence 20 (1), 62 and United Nations Assistance Mission to Afghanistan, 2007.

Global Islamic Media Front (Moharam 1429) "A message to the Mujahideen in particular and Muslims in general by Abu Mansoor Al Ameriki”.

Hafez, Mohammed M. (2006), "Suicide Terrorism in Iraq; A preliminary assessment of the Quantitative Data and Documentary Evidence", Studies in Conflict \& Terrorism 29 (6).

Hafez, Mohammed M. (2006b), Manufacturing Human Bombs, Washington, United States Institute of Peace.

Hansen, Stig Jarle (2007), Doktrineutvikling I Heimevernet, Oslo; Abstrakt forlag.

Hansen, Stig Jarle (2008), “Misspent Youth”, Jane's Intelligence Review 10.

Hansen, Stig Jarle (2009) "Somalia - Grievance, Religion, Clan, and Profit" in Hansen, Mesøy \& Kardas (2009), Borders of Islam, Colombia University press, London.

Harowo, "Somaliland blames suicide attack on Al Shebab", http://harowo.com/2008/11/28/ somaliland-blames-oct-suicide-attacks-on-shebab-group/ (accessed 25/03 2009).

Hegghammer, Thomas (2009), "Apostates vs. infidels: explaining differential use of suicide bombings by jihadist groups". Paper presented at the conference "Understanding Jihadism: Origins, Evolution and Future Perspectives”, Oslo, 19-21 March 2009.

Hoffman, Bruce (2005), “Security for a New Century,” Washington, D.C., September 23, (briefing for Senate Foreign Affairs Committee staff).

Hopgood, Stephen (2005), "Tamil Tigers (1987-2002)" in Diego Gambetta (ed.), Making Sense of Suicide Missions, Oxford, Oxford University Press, 54.

International Crisis Group (2005a), "Counter-Terrorism in Somalia: Losing Hearts and Minds?" Africa Report no. 95, 11 July.

International Crisis Group (2005b), “Somalia's Islamists”, Africa Report no. 100, 12 December.

Kataiib, "Taariikhda Shahiid Bi'idnillaah Amir Abdul Muhaymin (Abu Xoriyah) Mujaahid Amerikaan ahaa", http://www.kataaib.info/sh/abuxoriyah.htm (accessed 25/03 2009).

Khosrokhavar, Farhad (2005), Allah's New Martyrs, London, Pluto Press.

Kier, Elisabet (1997), Imagining War, Princeton, Princeton University Press.

Kimhi, Shaul and Shemuel Even (2004), "Who are the Palestinian Suicide Bombers?" Terrorism and Political Violence 16 (4). 


\title{
Journal of Terrorism Research
}

\author{
Volume 1, Issue 1
}

Lindner, Evelin G. (2001), "Humiliation as the source of terrorism: A new paradigm". Available at: http://web.lexis-nexis.com/universe/document (accessed April 26 2002).

Moghadam, Assaf (2006), "Suicide Terrorism, Occupation and the Globalization of Martyrdom: A Critique of Dying to Win" Studies in Conflict \& Terrorism 29 (8), 715.

Moghadam, Assaf (2008), The Globalization of Martyrdom: Al Qaeda, Salafi Jihad, and the Diffusion of Suicide Attacks. Johns Hopkins University Press, Baltimore.

Mujahideen Youth Movement, Al Qosra Army, Media section (date unknown) "The series of martyrdom operations in Somalia, Martyrdom operation number nine”, MYM/ Al Qosra army.

Pape, Robert A. 2005, Dying to Win, New York, Random House.

Pedahzur, Ami (2005), Suicide Terrorism, Malden, Polity Press.

Pedahzur, Ami \& Arie Perliger (2006), "The Changing Nature of Suicide Attacks", Social forces 84 (4).

Reuter, Christoph (2004). My Life Is a Weapon: A Modern History of Suicide Bombing, Princeton, NJ, Princeton University Press.

Rice, Xan "400 die in Mogadishu's worst fighting for 15 years”, The Guardian, Tuesday 3 April 2007.

Ricolfi, Luka (2003), "Palestinians 1981-2003” in Diego Gambetta (ed.), Making Sense of Suicide Missions, Oxford, Oxford University Press, 111.

Sageman, Marc, 2004, Understanding terror networks, Philadelphia, University of Pennsylvania Press.

Sheik Fuad Khalif, "Shongola" "The reality of the Alliance for the Re-liberation of Somalia Part I",

http://www.youtube.com/watch?

$\mathrm{v}=\mathrm{kPTmTsQP9} w \mathrm{w} \&$ feature $=$ PlayList $\& \mathrm{p}=825 \mathrm{D} 79 \mathrm{CE} 89315709 \&$ index $=2$ (accessed on 23 April 2009).

Sheik Fuad Khalif Shongola, "The reality of the Alliance for the Re-liberation of Somalia Part II", http://www.youtube.com/watch?

$\mathrm{v}=\mathrm{kPTmTsQP9} w \mathrm{w} \&$ feature $=$ PlayList $\& \mathrm{p}=825 \mathrm{D} 79 \mathrm{CE} 89315709 \&$ index $=2$ (acessed on 23 April 2009). 


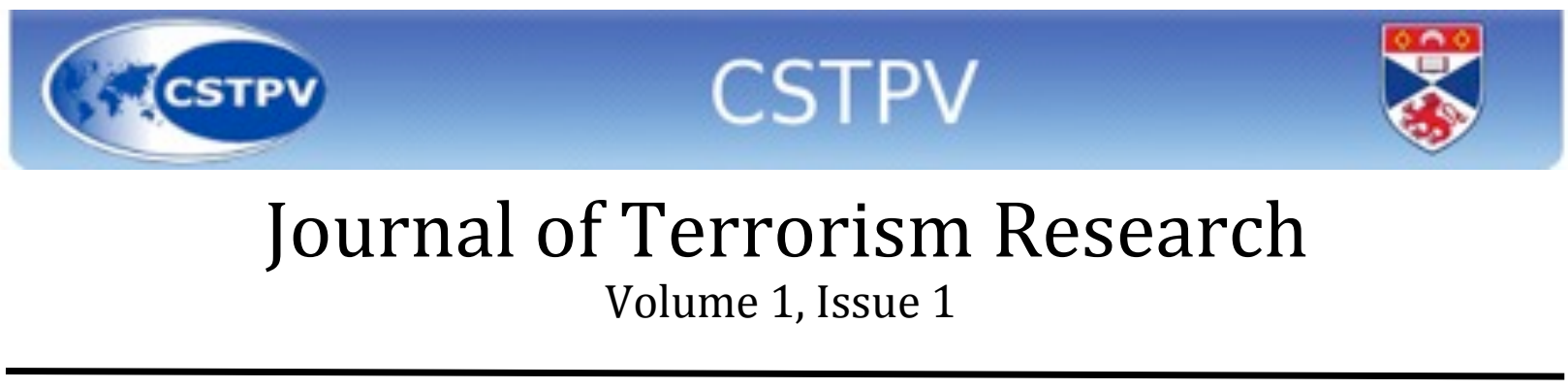

Speckhard, Anne \& Akhmedova, Khapta (2006), "The New Chechen Jihad: Militant Wahhabism as a Radical Movement and a Source of Suicide Terrorism in Post-War Chechen Society", Democracy \& Security 2 (1) 2006.

Staff writer, "Somali Islamists claim car bomb attack", Mail \& Guardian, 30 November 2006.

Staff writer, "U.N. says 90,000 refugees return to Mogadishu”, Reuters, 1 June 2007.

Stern, Jessica (2003), Terror in the Name of God: Why Religious Militants Kill, New York, Ecco/ Harper Collins.

United Nations Assistance Mission to Afghanistan (2007), Suicide Attacks in Afghanistan (2001-2007), Washington, United Nations.

United Nations in Somalia “The Djibouti agreement”, http://www.un-somalia.org/

Djibouti_Agreement/index.asp (accessed 1 March 2009).

United Nations Office for the Coordination of Humanitarian Affairs, Nairobi (2007), "Situation Report” Situation Report \#41, 8 June.

Victor, Barbara (2003), Army of Roses: Inside the World of Palestinian Women Suicide Bombers, Emmaus, PA, Rodale Press.

\section{Interviews}

Interview with anonymous Nigerian diplomat x1, Nairobi, 5 December 2008.

Interview with x2, Mogadishu, 2 April 2009.

Interview with Sheik x3, Mogadishu, 4 April 2009.

Interview with Sheik x4, Mogadishu, 5 April 2009.

Interview with x5, Mogadishu, 6 April 2009.

Interview with x6, Mogadishu, 8 August 2009.

Interview with x7, Mogadishu, 8 August 2009.

Interviews with Al Khala's leader Sheik Khalil Ameer, 24 July 2009, Khartoum.

Interview with Ikhwan spokesman Ali Gawish, 26 July 2009.

Interview (telephone) with Abu Mansoor, Mogadishu/Nairobi, 20 September 2008.

Interview (telephone) with Paddy Anakunda, ex- press spokesman for the African Union Forces Mogadishu, Oslo, 15 April 2008.

\section{Notes}




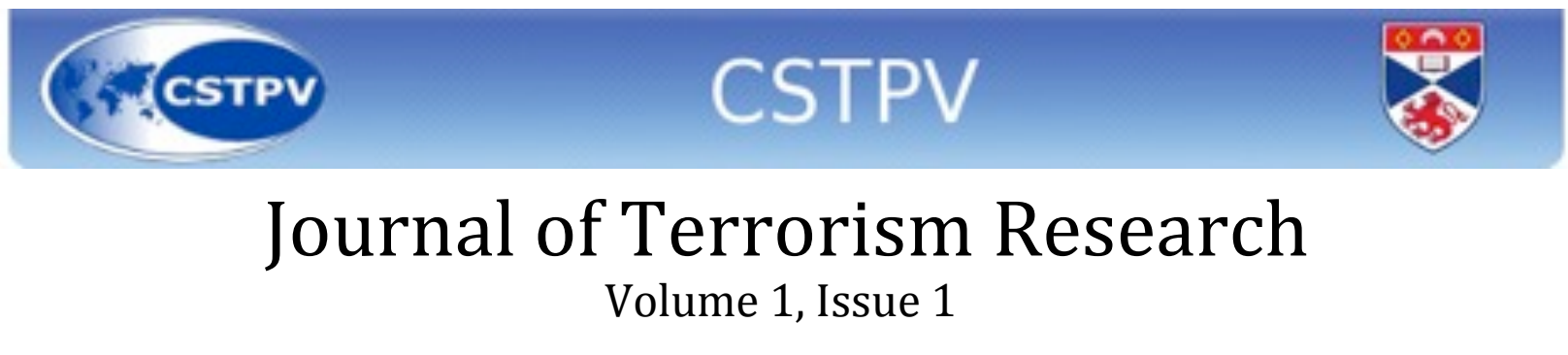

[1] See United Nations Assistance Mission to Afghanistan, 2007, Suicide Attacks in Afghanistan (2001-2007), Washington: United Nations; Speckhard, Anne \& Akhmedova, Khapta, "The New Chechen Jihad: Militant Wahhabism as a Radical Movement and a Source of Suicide Terrorism in Post-War Chechen Society", Democracy \& Security 2 (1) 2006; Bunker, Robert J. and John P. Sullivan, "Suicide Bombings in Operation Iraqi Freedom", Military Review, January-February 2005. Modern suicide attacks are often claimed to have started on 15 December 1981, when a suicide car bomb hit the Iraqi embassy in Lebanon. However, such an account fails to take into consideration the drastic change in the frequency and geographical scope after the end of the millennium.

[2] Hoffman, Bruce, "Security for a New Century", Washington D.C., September 23, 2005 (briefing for Senate Foreign Affairs Committee staff).

[3] For cases where suicide bombers have had fewer social, psychological and economic problems compared with the population, see for example Davis, Joyce M., 2003, Martyrs: Innocence, Vengeance and Despair in the Middle East, New York: Palgrave; Stern, Jessica, 2003, Terror in the Name of God: Why Religious Militants Kill, New York: Ecco/Harper Collins, 2003; Victor, Barbara, 2003, Army of Roses: Inside the World of Palestinian Women Suicide Bombers, Emmaus, PA: Rodale Press, 2003; Reuter, Christoph, 2004, My Life Is a Weapon: A Modern History of Suicide Bombing, Princeton, NJ: Princeton University Press. For notable exceptions see Speckhard, Anne \& Akhmedova, Khapta, "The New Chechen Jihad: Militant Wahhabism as a Radical Movement and a Source of Suicide Terrorism in Post-War Chechen Society", Democracy \& Security 2 (1) 2006, 23 (psychological traumas) and Fair, Christina, Who are the Pakistani Militants and Their Families, Terrorism and Political Violence 20 (1), 62 and United Nations Assistance Mission to Afghanistan, 2007. Hopgood, Stephen (2005) "Tamil Tigers 1987-2002" in Diego Gambetta (ed.) Making Sense of Suicide Missions, Oxford, Oxford University Press, 54. Several organisations, for example the Tamil Tigers, even have screening processes to remove candidates with personal problems.

[4] See, for example, Diego Gambetta (ed.), Making Sense of Suicide Missions, Oxford, Oxford University Press, 261. The most regular user of suicide attacks over the last 100 years is imperial Japan.

[5] The above reasoning is based on the assumption that organisations employing suicide attacks are relatively unitary.. Together with Arie Perliger, Pedahzur stresses the importance of social network theory in order to explain how independent cells within non-hierarchical organisations adopt suicide strategies. According to a network perspective, suicide bombers are seen as individuals joining on an ad hoc basis, with little training from their own organisation. Thus the power struggle between local groups becomes more important, influencing both the adoption and the frequency of suicide attacks, so we nevertheless speak of a form of local organisation. Pedahzur, Ami \& Perliger, Arie, (2006), "The Changing Nature of Suicide Attacks", Social forces 84 (4).

[6] Pape, Robert A., (2005), Dying to Win, New York: Random House.

[7] Moghadam, Assaf, (2006), "Suicide Terrorism, Occupation and the Globalisation of Martyrdom: A Critique of Dying to Win", Studies in Conflict \& Terrorism 29 (8), 715.

[8] Brym, Robert J. \& Araj, Bader, (2006), "Suicide Bombings as Strategy and Interaction: The Case of the Second Intifada", Social Forces, 84 (4).

[9] Hafez, Mohammed M., (2006), "Suicide Terrorism in Iraq; A Preliminary Assessment of the Quantitative Data and Documentary Evidence", Studies in Conflict \& Terrorism 29 (6).

[10] In the case of Iraq, Mohammed M. Hafez argues that suicide attacks can be seen as a tool by anti-government groups to draw attention to the failures of the government in providing security. Ibid 604 .

[11] Ibid. 26.

[12] Berman, E. and Latin, D., (2008), "Religion, Terrorism and Public Good, testing the club model”, Working Paper 13725.

[13] Bloom, 2005.

[14] Pedahzur, Ami, (2005), Suicide Terrorism, Malden: Polity Press, 27; Berman, E. and Latin, D., (2004), "Rational Martyrs, Evidence from Suicide Attacks", paper presented at the conference on suicide bombing, Stanford, September 2003. Hopgood, Stephen, (2005), "Tamil Tigers (1987-2002)" in Diego Gambetta (ed.), Making Sense of Suicide Missions, Oxford, Oxford University Press, 54.

[15] Berman, E. and Latin, D., (2008), "Religion, Terrorism and Public Good, testing the club model”, Working Paper 13725, 28-29. For example, the Eritrean People's Liberation Front (EPLF) and the Tigray People's Liberation Front (TPLF) in their early phases, which demanded a high sacrifice from members and provided welfare services.

[16] An organisational rational-focused exploration of suicide attacks as a military strategy should also draw upon the works on military doctrine and strategy within political science. So far this has been neglected, see Hansen, Stig Jarle, (2007), Doktrineutvikling i Heimevernet, Oslo: Abstrakt forlag.

[17] Rui de Figueiredo and Barry Weingast, "Vicious Cycles: Endogenous Political Extremism and Political Violence" (paper presented at the annual meeting of the American Political Science Association, Boston, September 1998).

[18] Brym, Robert J. \& Araj, Bader, 2006.

[19] Araj, Bader, 2008. 


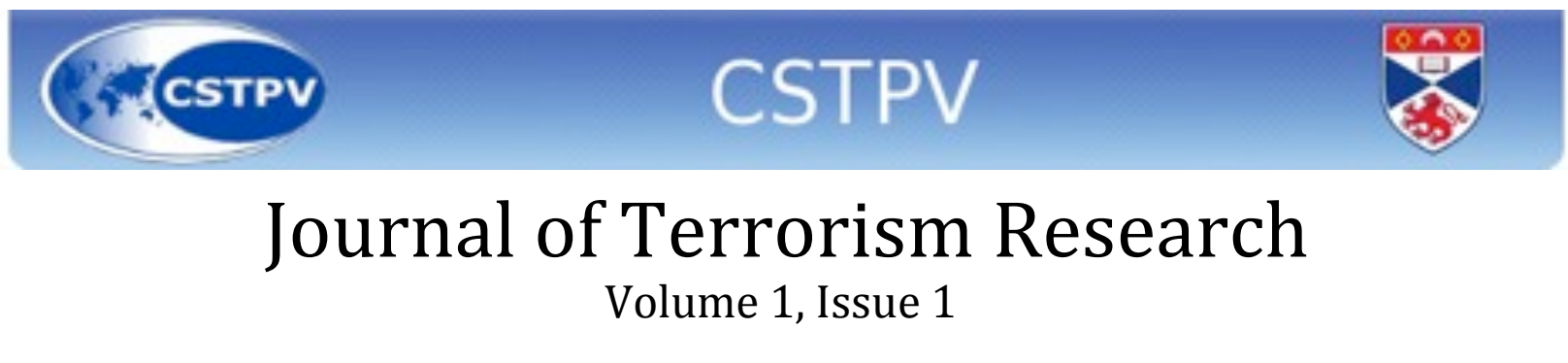

[20] Ibid. 291.

[21] Lindner, Evelin G., (2001), "Humiliation as the source of terrorism: A new paradigm". Available: http://web.lexis-nexis.com/universe/ document (accessed 26 April 2002).

[22] Ricolfi, Luka, (2003), "Palestinians 1981-2003" in Diego Gambetta (ed.), Making Sense of Suicide Missions, Oxford, Oxford University Press, 111.

[23] Harsh repressions of the Somali Ogadeen in Ethiopia, large-scale killings in Somalia, and disappearances in Kenya under the Moi regime have not resulted in suicide bombings, nor did the Ethiopian invasions of Somalia in 1996 and 1998 or the American intervention in Mogadishu in the early 1990 s.

[24] Hegghammer, Thomas, (2009), "Apostates vs. infidels: explaining differential use of suicide bombings by jihadist groups". Paper presented at the conference "Understanding Jihadism: Origins, Evolution and Future Perspectives", Oslo, 19-21 March 2009, 5.

[25] Bloom, Mia, (2005), Dying to kill, the allure of suicide terrorism, New York: Colombia University Press.

[26] Bukay, David, “The Religious Foundations of Suicide Bombings: Islamist Ideology”, Middle East Quarterly, Fall 2006.

[27] Dale, Stephen, (1988), "Religious suicides in Islamic Asia: Anticolonial Terrorism in India, Indonesia and the Philippines", Journal of Conflict Resolution, 23.

[28] Assaf Moghadam, (2008), The Globalization of Martyrdom: Al Qaeda, Salafi Jihad, and the Diffusion of Suicide Attacks. Baltimore: Johns Hopkins University Press.

[29] Interviews with Al Khala's leader Sheik Khalil Ameer, 24 July 2009, Khartoum. Interview with Ikhwan spokesman Ali Gawish, 26 July 2009.

[30] In fact, Hegghammer suggests that it is other mechanisms at work. Hegghammer, Thomas, (2009), "Apostates vs. infidels: explaining differential use of suicide bombings by jihadist groups". Paper presented at the conference "Understanding Jihadism: Origins, Evolution and Future Perspectives", Oslo, 19-21 March 2009, 5.

[31] Gambetta, Diego, (2003), "Can we make sense of suicide bombings" in Diego Gambetta (ed.), Making Sense of Suicide Missions, Oxford, Oxford University Press, 286. Hafez, Mohammed M., (2006), Manufacturing Human Bombs, Washington, United States Institute of Peace, 72. Khosrokhavar, Farhad, (2005), Allah's New Martyrs, London, Pluto Press.

[32] Kier, Elisabet, (1997), Imagining War, Princeton, Princeton University Press.

[33] The first involvement of Somalis in the planning and execution of suicide attacks may have been on 7 October 1998, when bombs exploded close to the American embassies in Nairobi and Dar es Salaam. Statements by the accused given after interrogations in American custody suggest that these attacks initially were planned as suicide attacks. It is important to note that the American legal indictment fails to mention any Somali involvement, although later statements made by American sources have implied that Somalis supported the operation logistically. It is unknown whether any Somali knew that the attacks were initially planned as suicide attacks. The first suicide attack in the Horn of Africa, on 28 November 2002, the Paradise Hotel attack in Kenya involving four suicide bombers, follows the same pattern in relation to Somali actors, albeit having a clearer link to Somalia. There are strong indications that individuals behind the attack, identified as Al Qaeda members by witnesses in American courts, used Somalia as a hideout, and had a close relationship with individuals who later were to become members of the main employers of suicide attacks in Somalia, the Harakat Al Shebab, aka the Youth. See International Crisis Group, (2005b), "Somalia's Islamists", Africa Report no. 100, 12 December, 11; International Crisis Group (2005a) “Counter-Terrorism in Somalia: Losing Hearts and Minds?", Africa Report no. 95, 11 July, 8.

[34] Two to three bombs exploded. The exact number of persons involved (as well as cars) varies from source to source but is said to be between one and four, including, according to some sources, a female suicide bomber in the plot.

[35] Staff writer, "Somali Islamists claim car bomb attack", Mail \& Guardian, 30 November 2006.

[36] Interview with anonymous x1, Mogadishu, 9 April 2009, and interview with anonymous x2, Mogadishu, 5 December 2006.

[37] Hansen, Stig Jarle (2008), "Misspent Youth”, Jane's Intelligence Review 10, 16. See also International Crisis group (2005a), International Crisis Group (2005b), "Somalia's Islamists", Africa Report no. 100.

[38] In November 2006, the writer visited Abokor Omar Adane's garage in Mogadishu. Adane was, at the time, the main financer of the courts. He promised that his 6614 Fiat armoured cars would be in Addis Ababa within months.

[39] The offensive also started approximately one month after Harakat Al Shebab restarted their activities on the Internet and claimed responsibility for other types of hit and run attacks against Ethiopia and their allies in the TFG.

[40] Neighbourhoods like Casa Populare (KPP) in the south, Towfiq and Ali Kamin around the stadium, all along Industrial Road, and the road from the stadium to Villa Somalia, were heavily shelled or repeatedly hit by Ethiopian BM-21 multiple-rocket launchers.

[41] Rice, Xan, “400 die in Mogadishu's worst fighting for 15 years”, The Guardian, Tuesday 3 April 2007. 


\title{
Journal of Terrorism Research
}

\author{
Volume 1, Issue 1
}

[42] Staff writer,"U.N. says 90,000 refugees return to Mogadishu”, Reuters, 1 June 2007; Rice, Xan, "400 die in Mogadishu's worst fighting for 15 years", The Guardian, Tuesday 3 April 2007.

[43] The first attack had been planned for a month. Adam Salad Adam had used the time to gain the friendship of the Ethiopians; it was thus planned before the Ethiopian offensives but was implemented after the Ethiopian offensive had started.

[44] All the attacks were highly successful; they had tangible military results and targeted Ethiopian bases in the Mogadishu area.

[45] Interview with anonymous x2, x3, x4, Mogadishu, November 2006. This can be seen when radicals used the black flag instead of the Somali flag during the battle for Kismayo that year, challenging the SCIC shura.

[46] The attack targeted the Hassi factory, close to the hotel where the TFG prime minister lived. The suicide bomber was Ahmad Hussayn Ahmad (using the name 'Abu Ayyub' on the suicide video). The 21-year-old British citizen of Somali origin was originally from Ealing; his suicide video was in English and concentrated on international jihadist rhetoric. The next attack was the attack by Abdulazzis Bashir Abdulahi on the forces of the African Union, which took place on 8 April 2008.

[47]United Nations in Somalia, “The Djibouti agreement”, http://www.un-somalia.org/Djibouti_Agreement/index.asp (accessed 01/03 2009).

[48] Five suicide bombers attacked Hargeisa in the relatively peaceful Somaliland enclave, an area never hit by suicide bombers before, targeting the Somaliland presidential palace, the Ethiopian trade mission office and the United Nations Development office. In a neighbouring region, Puntland, the offices of the American-trained Puntland Intelligence Service, in the city of Bosasso, was hit by two suicide bombers.

[49] An American citizen, Abdihraman Shirwa, was later identified as one of the suicide bombers, being the first American citizen to have acted as a suicide bomber. Shirwa was from Minnesota, and other Minnesota Somalians allegedly disappeared at the same time. Sources in the Hargeisa police claimed a link with Shebab leaders, however little evidence for this link has been forthcoming. Sources within the Somaliland police also claimed that three of the suicide bombers had been from the region, and had been detained but later released for previous terror attacks against Western aid workers in Somaliland. Unconfirmed reports from police investigations indicated that two explosive experts of Pakistan/Bengali origins were paid to transport and make the explosives used in the triple suicide-bomb attack. The Harakat Al Shebab has been implicated in the attacks but has never taken responsibility for them - a relatively new phenomenon, as the organisation has taken responsibility for most of the other suicide attacks and the attack was blessed by a Shebab sheik in Kismayo. Interview with anonymous Nigerian diplomat x1, Nairobi December 2008

[50] The suicide bombers were Ahmed Sheikhdon Sidow Wehliye and Mursal Abdinur Mohamed Ali. For more information, refer to AllAfrica/ garrowe online, "Somalia: 11 African Union Peacekeepers Killed", http://allafrica.com/stories/200902230003.html (accessed 23 March 2009), see http://anikah.wordpress.com/2009/02/ (accessed 23 March 2009) for the Shebab's own pictures.

[51] Hoffman, 2005.

[52] The Shebab have so far taken public responsibility for 14 out of 20 confirmed suicide attacks, and are accused by the Somaliland authorities of planning five more (no denial has been issued by the Shebab). The suicide video from Abdulazzis Bashir Abdulahi presents the first nine suicide bombers, see Mujaheedin Youth Movement, Al Qosra Army, Media section (date unknown), "The series of martyrdom operations in Somalia, Martyrdom operation number nine", MYM/Al Qosra army. See also Harowo, "Somaliland blames suicide attack on Al Shebab", http:// harowo.com/2008/11/28/somaliland-blames-oct-suicide-attacks-on-shebab-group/ (accessed 25 March 2009). The Shebab have published intimate details regarding the suicide bombings on their homepages, details that indicate in-depth knowledge of the suicide attacks and that the claims are valid.

[53] At the time of writing, there are five confirmed suicide attacks that no party has publicly taken responsibility for; these attacks are the Hargeisa/Bosasso 29 October 2009 suicide bombing wave. The Shebab is accused by the Somaliland authorities of being behind these attacks.

[54] Several of the Shebab's rivals have been in high-pressured tactical situations, such as when facing the March-April 2007 TFG/Ethiopian offence, nevertheless they have abstained from employing suicide bombing as a strategy.

[55] Interview with x5, Mogadishu, 2 April, 2009.

[56] Thomas Hegghammer makes a serious empirical mistake when claiming that the Sharia court alliance has existed since 1994 but only implemented attacks in 2006. Various alliances have existed and disappeared, but the 2006 alliance was driven by three specific courts (some courts refused to join while others joined quite late). The Shishi, the Ifka Halane and the Circola courts drove the development. See Stig Jarle Hansen (2009), "Somalia - Grievance, Religion, Clan, and Profit" in Hansen, Mesøy \& Kardas, (2009), Borders of Islam, Colombia University Press, London. The court union of 2006 was formed informally in 2005, and only formalised in 2006.

[57] Hansen, Stig Jarle, “Misspent Youth, Somalia's Shabab insurgents”, Jane’s Intelligence Review, 2008, 20 (10).

[58] Interview with anonymous human rights (x6 and x7) activists in Baidoa, summer 2009. The writer had the fortune to work with these activists over time. It is very interesting that these local sources correctly read the conflict between Abu Mansoor and Abu Zubeir, that many predicted would lead to a split in the Shebab from 2008 and onwards. The local sources claimed that this was impossible as the indoctrination radical elements made it impossible for Mansoor to trust his own militia.

[59] Al Jazeera, “Interview with Mukthar Robow Abu Mansoor”, Al Jazeera, 7 March 2009. 


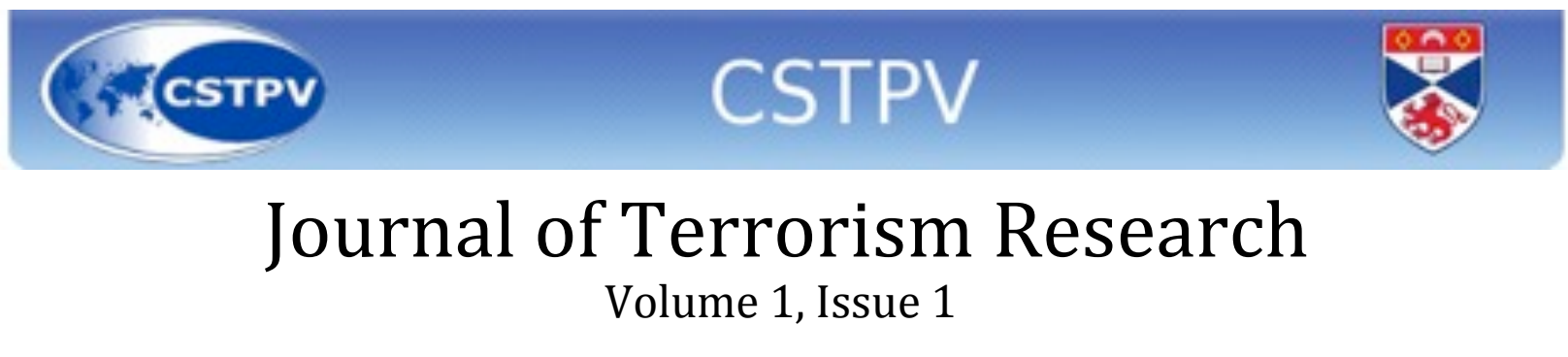

[60] Telephone interview with Abu Mansoor, Mogadishu/Nairobi, 20 September 2008. Al Jazeera, "Interview with Mukthar Robow Abu Mansoor" as aired on Al Jazeera, 7 March 2009.

[61] Khosrokhavar, Farhad, (2005), Allah's New Martyrs, London, Pluto Press.

[62] The writer of this article conducted a survey of one of the major news web pages in Somalia. In the period 2007-2009, the Shabelle news and other Islamist factions made no claims in a pan-Islamic direction. According to Abu Mansoor Al Ameriki, the Sharia court leadership even banned foreign fighters from entering Somalia in 2006. Global Islamic Media Front, "A message to the Mujahideen in particular and Muslims in general by Abu Mansoor Al Ameriki”, Moharam 1429.

[63] Abu Bakr Karshi, 2008.

[64] Speech/movie by Sheik Fuad Khalif Shongola, "The reality of Alliance for the Re-liberation of Somalia Part I", http://www.youtube.com/ watch? $\mathrm{v}=\mathrm{kPTmTsQP9}$ ww\&feature=PlayList\&p=825D79CE89315709\&index=2 (accessed on 23 April 2009).

[65] Hansen, Stig Jarle (2008), “Misspent Youth”, Jane's Intelligence Review 10.

[66] Al Jazeera, 7 March 2009.

[67] See for example Ibid. Al Jazeera, "Interview with Mukthar Robow Abu Mansoor" as aired on Al Jazeera 7 March 2009 . Interview x4 and x5. The conflict between the two seems to have been created by allegations that Muqtar Robow was too lenient upon captured TFG political leaders from his own clan, allowing them to leave, and the quick rise in Robow's power may also have frightened Zubeir. However, by the summer of 2009, the problem seemed to be solved by Muqtar Robow when he stepped down as the Shebab's spokesperson and promised to kill the most notable member of the TFG he had allowed to go, Muhammed Ibrahim Hapsade.

[68] The suicide film of Abu Ayyuub al-Muhajir can serve as an example of the special Shebab ideology, as described above, and depicts Abdullah Azzam, Abu Musab al-Zarqawi and the Hamas leader Sheikh Yasin, as well as the Chechnya leader Khatab. The film also displays Osama bin Laden looming over a movie depicting the attack in Baidoa, as well as a short interview with the latter at the end of the film. The latest speech (at the time of writing) of Abu Zubeyr starts with the lines "Peace be upon the Amir of believers, Mullah Mohammed Omar, who has been very patient and did Jihad in the cause of Allah, Peace be upon our Sheik and Amir Sheikh Osama bin Laden the Mujahid, and Peace be upon Sheikh Murabit who has lived for Jihad and in Jihad, Sheikh Ayman al-Zawahiri". Muqtar Robow confirmed his similar statements made in the Al Jihad magazine on the telephone with the writer of this article in November 2008, although most of the web pages previously (until autumn 2008) had intimate and updated details of clashes involving Shebab forces all over Somalia, indicating connections with the field forces of Al Shebab. Similar views were expressed in movies with the leaders posted on YouTube, and in interviews with the local press. See for example Al Jazeera, 7 March 2009, speech/movie by Sheik Fuad Khalif Shongola, "The reality of Alliance for the Re-liberation of Somalia Part I", http:// www.youtube.com/watch?v=kPTmTsQP9ww\&feature=PlayList\&p=825D79CE89315709\&index=2 (accessed on 23 April 2009); speech/movie by Sheik Fuad Khalif Shongola, "The reality of Alliance for the Re-liberation of Somalia Part II", http://www.youtube.com/watch? $\mathrm{v}=\mathrm{kPTmTs} Q P 9 \mathrm{ww} \&$ feature=PlayList\&p=825D79CE89315709\&index=2 (accessed on 23 April 2009); Abu Bakr Karshi, 2008, “An interview with commander Abu Mansoor, Muqtar Robow", Sada al-Jihad Magazine, Global Islamic Media Front, 25 (3), Al Shebab (accessed on 23 April 2009).

[69] The background of several Shebab leaders can illuminate the dynamics behind this belief system. Leaders such as Ibrahim Afghani, the late Aden Hashi Ayro, Abdi Godane and Muqtar Robow had been trained in Afghanistan, if one believes Robow's statement that the organisation was headed by a shura of 8 persons, which means that the majority of the leaders were Afghanistan alumni. Muqtar Robow described the origins of the organisation: "Al Shebab was formed not too long ago after people returned from the fighting in Afghanistan in which the Taliban was ousted", interview with "Mukthar Robow Abu Mansoor", Al Jazeera, 7 March 2009. Telephone interview with Abu Mansoor, Mogadishu, 20 September 2008

[70] International Crisis Group, (2005a), “Counter-Terrorism in Somalia: Losing Hearts and Minds?”, Africa Report no. 95, 11 July, 8. 


\title{
Journal of Terrorism Research
}

\author{
Volume 1, Issue 1
}

Appendix 1: Suicide attacks in Somalia January 2006-April 2010

\begin{tabular}{|c|c|c|c|c|c|}
\hline Date & Target & $\begin{array}{l}\text { Confirmed as a suicide } \\
\text { attack by more than one } \\
\text { independent source (yes/ } \\
\text { no) }\end{array}$ & $\begin{array}{l}\text { Organisation claiming } \\
\text { responsibility }\end{array}$ & $\begin{array}{l}\text { Suicide video } \\
\text { issued (yes/no) }\end{array}$ & $\begin{array}{l}\text { Name of suicide } \\
\text { bomber }\end{array}$ \\
\hline \begin{tabular}{|l|}
19 \\
Septembe \\
r 2006 \\
\end{tabular} & $\begin{array}{l}\text { Car convoy with } \\
\text { Somali President } \\
\text { Yusuf in Baidoa }\end{array}$ & $\begin{array}{l}\text { No, several sources } \\
\text { describe it as an ambush } \\
\text { only. }\end{array}$ & None & No & None given \\
\hline \begin{tabular}{|l|}
30 \\
Novembe \\
r 2006
\end{tabular} & $\begin{array}{l}\text { Somali road block } \\
\text { outside Baidoa }\end{array}$ & Yes & $\begin{array}{l}\text { Mohamed Ibrahim Said } \\
\text { Bilal, militia } \\
\text { commander, Al Bayan } \\
\text { court claim } \\
\text { responsibility, Bilal } \\
\text { close to radicals later } \\
\text { joining Shebab }\end{array}$ & $\begin{array}{l}\text { Suicide } \\
\text { bomber } \\
\text { depicted on } \\
\text { later video }\end{array}$ & $\begin{array}{l}\text { None given, } \\
\text { possibly involved } \\
\text { two bombers }\end{array}$ \\
\hline $\begin{array}{l}26 \text { March } \\
2007\end{array}$ & $\begin{array}{l}\text { Ethiopian base in } \\
\text { Mogadishu }\end{array}$ & Yes & Harakat Al Shebab & Yes & $\begin{array}{l}\text { Adam Salad } \\
\text { Adam 'Okiyo' }\end{array}$ \\
\hline $\begin{array}{l}19 \text { April } \\
2007\end{array}$ & $\begin{array}{l}\text { Ethiopian base in } \\
\text { Mogadishu }\end{array}$ & Yes & Harakat Al Shebab & Yes & $\begin{array}{l}\text { Abdul-Aziz } \\
\text { Dawood Abdul- } \\
\text { Qader }\end{array}$ \\
\hline $\begin{array}{l}24 \text { April } \\
2007\end{array}$ & $\begin{array}{l}\text { Ethiopian base in } \\
\text { Afgoye }\end{array}$ & Yes & Harakat Al Shebab & Yes & $\begin{array}{l}\text { Othman Otayo } \\
\text { (otibo) al-Kini }\end{array}$ \\
\hline $\begin{array}{l}25 \text { April } \\
2007\end{array}$ & $\begin{array}{l}\text { Hotel in } \\
\text { Mogadishu }\end{array}$ & $\begin{array}{l}\text { No, only one source says } \\
\text { it was a suicide attack, } \\
\text { other sources claim it was } \\
\text { a bomb. }\end{array}$ & None & No & Not known \\
\hline $\begin{array}{l}7 \text { May } \\
2007\end{array}$ & $\begin{array}{l}\text { African Union } \\
\text { forces }\end{array}$ & $\begin{array}{l}\text { No, AU is not sure if it } \\
\text { was a suicide attack or } \\
\text { not. The attack was } \\
\text { conducted with a } \\
\text { wheelbarrow. }\end{array}$ & None & No & Not known \\
\hline $\begin{array}{l}3 \text { June } \\
2007\end{array}$ & $\begin{array}{l}\text { Prime minister } \\
\text { Gedi's house in } \\
\text { Mogadishu }\end{array}$ & Yes & Harakat Al Shebab & Yes & $\begin{array}{l}\text { Abdul-Aziz } \\
\text { Mohammad } \\
\text { Semter }\end{array}$ \\
\hline $\begin{array}{l}4 \text { June } \\
2007\end{array}$ & $\begin{array}{l}\text { Ethiopian Road } \\
\text { block, possibly the } \\
\text { United Nations }\end{array}$ & Yes & Harakat Al Shebab & Yes & $\begin{array}{l}\text { Abu bakr sidi } \\
\text { hiray }\end{array}$ \\
\hline
\end{tabular}




\section{Journal of Terrorism Research}

\section{Volume 1, Issue 1}

\begin{tabular}{|c|c|c|c|c|c|}
\hline $\begin{array}{l}1 \text { July } \\
2007\end{array}$ & $\begin{array}{l}\text { Arrested before } \\
\text { attack in Baidoa } \\
\text { (unknown) }\end{array}$ & No & None & No & $\begin{array}{l}\text { Female arrested, } \\
\text { accused of being } \\
\text { the suicide } \\
\text { bomber }\end{array}$ \\
\hline \begin{tabular}{|l|}
10 \\
October \\
2007
\end{tabular} & $\begin{array}{l}\text { Ethiopian Base in } \\
\text { Baidoa }\end{array}$ & Yes & Harakat Al Shebab & Yes & $\begin{array}{l}\text { Ahmad Hussayn } \\
\text { Ahmad (alias } \\
\text { Abu Ayyub) }\end{array}$ \\
\hline $\begin{array}{l}8 \text { April } \\
2008\end{array}$ & $\begin{array}{l}\text { African Union } \\
\text { base in Mogadishu }\end{array}$ & Yes & Harakat Al Shebab & Yes & $\begin{array}{l}\text { Abdulazzis } \\
\text { Bashir } \\
\text { Abdulahi }\end{array}$ \\
\hline \begin{tabular}{|l}
29 \\
October \\
2008
\end{tabular} & $\begin{array}{l}\text { PIS base in } \\
\text { Bosasso }\end{array}$ & Yes & $\begin{array}{l}\text { Not claimed but blessed } \\
\text { by Shebab sheik in } \\
\text { Kismayo }\end{array}$ & No & Shirwa Ahmed \\
\hline \begin{tabular}{|l}
9 \\
October \\
2008
\end{tabular} & UNDP Hargeisa & Yes & $\begin{array}{l}\text { Not claimed but alleged } \\
\text { by Somaliland to be } \\
\text { Shebab, blessed by } \\
\text { Shebab sheik in } \\
\text { Kismayo }\end{array}$ & No & Not known \\
\hline \begin{tabular}{|l}
9 \\
October \\
2008
\end{tabular} & $\begin{array}{l}\text { Ethiopian trade } \\
\text { mission in } \\
\text { Hargeisa }\end{array}$ & Yes & $\begin{array}{l}\text { Not claimed but alleged } \\
\text { by Somaliland to be } \\
\text { Shebab, blessed by } \\
\text { Shebab sheik in } \\
\text { Kismayo }\end{array}$ & No & Not known \\
\hline $\begin{array}{l}29 \\
\text { October } \\
2008\end{array}$ & $\begin{array}{l}\text { Somaliland } \\
\text { presidential palace } \\
\text { in Hargeisa }\end{array}$ & Yes & \begin{tabular}{|l|} 
Not claimed but alleged \\
by Somaliland to be \\
Shebab, blessed by \\
Shebab sheik in \\
Kismayo
\end{tabular} & No & Not known \\
\hline \begin{tabular}{|l}
24 \\
January \\
2009
\end{tabular} & Roadblock & No & Not claimed & No & Not known \\
\hline \begin{tabular}{|l|}
21 \\
February \\
2009
\end{tabular} & $\begin{array}{l}\text { AU base in } \\
\text { Mogadishu }\end{array}$ & Yes & Harakat Al Shebab & Yes & $\begin{array}{l}\text { Ahmed } \\
\text { Sheikhodn Sidow } \\
\text { Wehliye }\end{array}$ \\
\hline \begin{tabular}{|l}
21 \\
February \\
2009 \\
\end{tabular} & $\begin{array}{l}\text { AU base in } \\
\text { Mogadishu }\end{array}$ & Yes & Harakat Al Shebab & Yes & $\begin{array}{l}\text { Mursal Abdinur } \\
\text { Mohamed Ali. }\end{array}$ \\
\hline \begin{tabular}{|l}
24 May \\
2009
\end{tabular} & $\begin{array}{l}\text { Government } \\
\text { (GNU) base in } \\
\text { Mogadishu }\end{array}$ & Yes & Harakat Al Shebab & $\begin{array}{l}\text { Not at the time } \\
\text { of writing }\end{array}$ & $\begin{array}{l}\text { Abdul Qader } \\
\text { Hassan } \\
\text { Mohammed }\end{array}$ \\
\hline $\begin{array}{l}18 \text { June } \\
2009\end{array}$ & $\begin{array}{l}\text { Ministers in the } \\
\text { new government }\end{array}$ & Yes & Harakat Al Shebab & yes & $\begin{array}{l}\text { Muxamed } \\
\text { Deerow (Diire) } \\
\text { Shiikh Aadam } \\
\text { (zubayr/ } \\
\text { Azzubay) }\end{array}$ \\
\hline
\end{tabular}




\begin{tabular}{|c|c|c|c|c|c|}
\hline \begin{tabular}{|l}
17 \\
Septembe \\
r 2009
\end{tabular} & \begin{tabular}{|l|} 
Al-Shabaab \\
suicide bombers \\
detonated two \\
vehicles bearing \\
UN logos at the \\
AMISOM Forces \\
headquarters in \\
Mogadishu, \\
killing nine \\
AMISOM \\
soldiers, and two \\
civilians, \\
including the \\
deputy force \\
Commander, Maj. \\
Gen. Juvenile \\
Niyoyunguriza.
\end{tabular} & Yes & Harakat Al Shebab & No & \\
\hline $\begin{array}{l}3 \\
\text { Decembe } \\
\text { r } 2009\end{array}$ & \begin{tabular}{|l|} 
Suicide attack on \\
graduation \\
sermony in Shamo \\
Hotel, \\
Mogadishu.Qamar \\
Aden Ali, the \\
health minister, \\
Ahmed Abdulahi \\
Waayeel, the \\
education \\
minister, and \\
Ibrahim Hassan \\
Addow, the higher \\
education \\
minister, all died \\
in the explosion \\
\end{tabular} & $\begin{array}{l}\text { Contested as a suicide } \\
\text { operation } \\
\end{array}$ & $\begin{array}{l}\text { Shebab explicitly } \\
\text { denies responsibility; } \\
\text { alleges that this is a } \\
\text { government operation }\end{array}$ & No & $\begin{array}{l}\text { Alleged to be a } \\
\text { Danish citizen, } \\
\text { but contested }\end{array}$ \\
\hline \begin{tabular}{|l}
6 \\
January \\
2010
\end{tabular} & \begin{tabular}{|l|} 
A suicide attacker \\
attacks a medical \\
Clinique close to \\
the airport and \\
often used by \\
African Union \\
personnel. The \\
attacker wore an \\
explosive jacket
\end{tabular} & Yes & Harakat Al Shebab & No & Not known \\
\hline
\end{tabular}




\section{Journal of Terrorism Research}

\section{Volume 1, Issue 1}

\begin{tabular}{|c|c|c|c|c|c|}
\hline \begin{tabular}{|l}
04 \\
February \\
2010
\end{tabular} & \begin{tabular}{|l|} 
Alleged suicide \\
attack against \\
Somaliland \\
Minister of \\
Interior Abdillahi \\
Ismail Ali (Irro) at \\
Hamdi Hotel Las \\
Anod, in the \\
contested Sool \\
province
\end{tabular} & $\begin{array}{l}\text { Alleged only by } \\
\text { Somaliland officials. It is } \\
\text { also claimed to be a } \\
\text { handgrenade attack }\end{array}$ & No & No & No \\
\hline \begin{tabular}{|l}
15 \\
February \\
2010
\end{tabular} & \begin{tabular}{|l|} 
Suicide attack, \\
combined with \\
road bombs (two) \\
against the convoy \\
of State Minister \\
for Defense \\
Sheikh Yusuf \\
Mohammad Siad, \\
who is better \\
known as \\
Indha'adde or \\
White Eyes \\
\end{tabular} & Yes & No & no & Not known \\
\hline $\begin{array}{l}27 \text { April, } \\
2010\end{array}$ & \begin{tabular}{|l|} 
Two attackers \\
drove a truck \\
filled with \\
explosives toward \\
a new AU \\
peacekeeping \\
base. Claimed to \\
be a revenge for \\
the killing of Al \\
Qaeda leaders in \\
Iraq.
\end{tabular} & Yes & Harakat Al Shebab & $\begin{array}{l}\text { Yes, the face of } \\
\text { one suicide } \\
\text { bomber } \\
\text { removed from } \\
\text { pictures. }\end{array}$ & $\begin{array}{l}\text { Ahmed } \\
\text { Mohamed Yusuf } \\
\text { and Abdulaahi } \\
\text { Yaasiin }\end{array}$ \\
\hline
\end{tabular}

